\title{
UNA ENSALADA ANÓNIMA DEL SIGLO XVII DE LOS ROMANCES Y LETRAS DE A TRES VOZES (Biblioteca Nacional de Madrid)
}

Mariano LAMBEA

\begin{abstract}
“Ortigosa. Ande, mi señora doña Lorenza, no se queje tanto; que con una caldera vieja se compra otra nueva.

LORENZA. Y aun con esos y otros semejantes villancicos o refranes me engañaron a mí."
\end{abstract}

Cervantes, Entremés del viejo celoso.

\section{Introducción}

Procedentes del Fondo Barbieri y bajo las signaturas M. 1370, M. 1371 y M. 1372, se conservan en la Biblioteca Nacional de Madrid tres volúmenes manuscritos ${ }^{1}$, en su mayor parte de polifonía profana, pertenecientes a las primeras décadas del siglo XVII. Aproximadamente la primera mitad de las piezas de esta compilación fueron publicadas por Miguel Querol ${ }^{2}$ en un único tomo, sin que hasta la fecha hayan visto la luz las restantes composiciones, al menos, agrupadas en un segundo volumen. Entre éstas, en las páginas 95-97 de los citados manuscritos, figura una "Ensalada a 3" de autor anónimo, que viene a engrosar el reducido, pero valioso, repertorio musical que poseemos hasta el momento sobre este género literariomusical tan típicamente hispánico, ya que, si atendemos al número de obras conservadas, las fuentes literarias que contienen ensaladas y ensaladillas han llegado siempre hasta nosotros en mayor medida que las fuentes específicamente musicales.

1. Cfr. Higinio Anglés y José Subirá, Catálogo Musical de la Biblioteca Nacional de Madrid, Barcelona, C.S.I.C., 1946, vol. I, pp. 260-265. Aquí aparecen descritos con su contenido íntegro de obras y autores, y bajo el epígrafe Cancionero Musical (siglo XVII). Con anterioridad el propio Anglés había dado una somera descripción de los mismos, incluyendo la relación de primeros versos y autores, en su libro Johannis Pujol, Opera omnia, vol I, Barcelona, Biblioteca de Cataluña, 1926, pp. XXI-XXII.

2. Miguel Querol Gavaldá, Romances y letras a tres vozes (Siglo XVII), Vol. I, Monumentos de la Música Española, XVIII, Barcelona, C.S.I.C., 1956. Para la descripción de los manuscritos vid. el capítulo I (pp. 9-13). 
En relación a la definición del término Ensalada, sobradamente conocidas son las que dieran Rengifo ${ }^{3}$, Covarrubias ${ }^{4}$ y el Diccionario de Autoridades ${ }^{5}$. Dichas definiciones resumen las características del género a tres o cuatro constantes, y resultan perfectamente aplicables a un determinado tipo de ensaladas, pero las aportaciones de la investigación filológica y musicológica obligan a perfilar más detenidamente la definición y a añadirle nuevas características, no sólo en los aspectos formales, sino también en el contenido temático e ideológico. En este sentido, no es exagerado reclamar una definición prácticamente exclusiva para cada ensalada en particular, sobre todo, si tenemos en cuenta tanto la parte literaria como la musical, y la sutil conjunción entre ambas. Autores de nuestro tiempo, procedentes de ámbitos filológicos, han estudiado el género en profundidad rastreando su desarrollo a partir de la canción lírica tradicional ${ }^{6}$-ya sea de raíz folklórica como de cancionero culto o cortesana-, y relacionándolo con el teatro, el romance, el villancico, el chiste ${ }^{7}$. Aunque es un género considerado generalmente como menor, su importancia en la vida espiritual de la época fue considerable como tendremos ocasión de comprobar.

No entra en el objetivo del presente trabajo realizar un estudio comparativo de esta ensalada con el resto del repertorio, tanto vocal como instrumental, puesto que ello excedería los límites de que dispongo. Sin duda sería una aportación muy interesante, así como una síntesis global o, mejor aún, una monografía de carácter literariomusical sobre el género. Pero esto quedará, pues, si conviene, para mejor ocasión.

3. Juan DíAz Rengifo, Arte poética española, Madrid, Imprenta de Francisco Martínez, 1644, p. 93: "De las ensaladas. Ensalada es una composición de coplas redondillas entre las quales se mezclan todas las diferencias de metros, no sólo españoles, pero de otras lenguas, sin orden de unos a otros, al alvedrío del poeta; y según la variedad de las letras se va mudando la música, y por esso se llama ensalada, por la mezcla de metros y sonadas que lleva. El exemplar va al fin deste Libro." En efecto, en las pp. 39-40 de una especie de apéndice figura una ensalada "A Christo recién nacido", cuyos primeros versos pertenecen al famoso estribillo "Dexadle llorar / orillas de la mar". Además de en castellano, hay texto en francés y en portugués, y la jerigonza peculiar del vizcaíno; no figura, en cambio, la síntesis final en latín, litúrgica o no, que suele dar término a la mayoría de ensaladas. Para la transcripción de textos antiguos en el presente trabajo utilizo siempre los criterios ortográficos expuestos por Margit FRENK en su Corpus de la antigua lírica popular hispánica (siglos XV a XVII), Madrid, Editorial Castalia, 1987, (2a ed.), p. xi del prólogo.

4. Sebastián de Covarrubias, Tesoro de la Lengua Castellana o Española según la impresión de 1611, con las adiciones de Benito Noydens publicadas en la de 1674, ed. por Martín de Riquer, Barcelona, S. A. Horta, I. E, 1943, p. 522: “... llamaron ensaladas un género de canciones que tienen diversos metros, y son como centones, recogidos de diversos autores. Éstas componen los maestros de capilla, para celebrar las fiestas de la Natividad; y tenemos de los autores antiguos muchas y muy buenas, como el molino, la bomba, el fuego, la justa, el chilindrón, etc."

5. Real Academia Española, Diccionario de Autoridades, ed. facs., Madrid, Ed. Gredos, 1976, vol II, p. 488: “... llamaron Ensaladas un género de canciones que tienen diversos metros: como son las letras de los villancicos, que se suelen cantar por Navidad, y en otros días solemnes y festivos."

6. Cfr. Margit Frenk Alatorre, Estudios sobre lírica antigua, Madrid, Ed. Castalia, 1978, p. 57; la definición que da me parece muy completa: "Son composiciones de cierta extensión en que se incrustan textos ajenos, las más veces canciones folklóricas y de moda, o versos de romances, o también refranes. Es difícil dar una definición más concreta del género, por la gran flexibilidad que lo caracteriza. Hay ensaladas escritas en una forma estrófica precisa (redondillas, quintillas, coplas reales, de arte menor $y$ de pie quebrado, romance o romancillo), otras que mezclan distintos tipos de estrofa, y otras, en fin, sin estructura estrófica alguna. En ciertas ensaladas el cantar citado forma parte de la estrofa, en otras queda fuera de ella. El cantar mismo puede reducirse a un estribillo o arrastrar su cauda de coplas al estilo antiguo o al estilo cortesano. El asunto de la ensalada puede ser religioso o profano; puede constituir un relato continuado o bien una yuxtaposición de episodios o una simple cadena de elementos inconexos y aun disparatados. En otras palabras, todo es posible en este género."

7. Cfr. José Romeu Figueras, "Mateo Flecha el Viejo, la corte literario musical del duque de Calabria y el Cancionero llamado de Upsala", Anuario Musical, XIII (1958), pp. 25-101. Por otra parte, en el apartado "La ensalada como género. Gil Vicente. Flecha el Viejo y las formas afines al género" (pp. 38-46 del artículo citado), Romeu define también el término, refiriéndose, además, a su genealogía y resaltando las características más acusadas de cada ensalada tratada en particular. 


\section{Transcripción del texto ${ }^{8}$}

A continuación transcribo la ensalada a partir de la voz más aguda ${ }^{9}$.

\section{Ensalada a 3}

[I]

Oy, Jil, en consejo abierto

vi que pedían audiencia

al Rey con gran reverencia

estando Él siempre cubierto.

5 Sentenciad entre los dos.

que sólo de un pan aquí

y un bocado que comí

me tiene muerto, por Dios.

\section{Copla}

Un portugués sacristán

10 me quiso hazer encreyentes

que el pan que tomé entre dientes

era carne, y no era pan.

Yo dije: - Comedlo vos,

que pan solamente vi

15 y un bocado que comí

me tiene muerto, por Dios.-

[II]

Llegó luego el portugués

que alegava su hidalguía

y a par de Dios se ponía,

20 y assí replicó después:

$$
\begin{gathered}
\text {-So muyto fidalgo } \\
\text { que naon fice tal, } \\
\text { ollay, }
\end{gathered}
$$

8. Vid. una transcripción parcial del texto de esta ensalada en Miguel Querol, "El villano de la época de Cervantes y Lope de Vega y su supervivencia en el folklore contemporáneo", Anuario Musical, XI (1956), p. 29.

9. Agradezo al Dr. Josep Romeu Figueras su amable colaboración en la revisión del texto poético, con su correspondiente puntuación y demás aspectos filológicos. Asimismo, debo a la Licda. Dolores Josa Fernández su valiosa ayuda en orientaciones bibliográficas y manejo de fuentes literarias. 


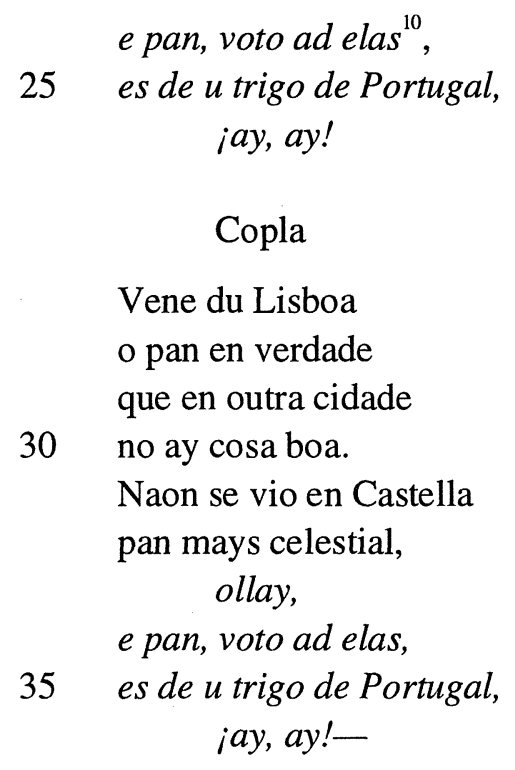

[III]

Vino acortando razones un hombre de buena ley, mas no le entendiera el Rey

40 a no entender corazones.

Servicios, o Rey, te hazes, pero tan pobre le dexas que para comer un blanca sólo le vienes de rrenta.

\section{Copla}

45 Al hombre que no le guardas el fe según le devieras, machete, sin que l'esperas, le cortas luego el orejas. Byzcaíno bien nacido, 50 de mí compassión le tengas, que para comer un blanca sólo le vienes de rrenta. 
[IV]

Por ver su condición franca, una gitana llegó

55 y desta suerte le habló para sacarle una blanca:

- ¡Ay, qué buenaventura te diré, mi alma, zi me das limoznita,

60 la cara de plata!

\section{Copla}

Muchos te querrán, tendrás vida larga, harás lo que quieres, nada te hará falta.

$65 i O$, qué buenaventura te diré, mi alma, zi me das limoznita, la cara de plata!-

\section{[V]}

Unos billanos venían

70 y entraron al Rey de hecho a sólo pagarle el pecho que del trigo le devían.

Y besándole la mano cantaron en su presencia,

75 baylando con eminencia, todos juntos un villano.

Al billano se la dan la ventura con el pan. 


$$
\text { Copla }
$$

Año bueno, Rey, tubimos

80 porque sembrando en el suelo

y ayudándonos el cielo

mucho pan al fin cogimos.

Mas, si Dios quiere y vivimos, si después nos lo comemos

85 más contentos quedaremos

que comiendo de un faisán.

Al billano se la dan

la ventura con el pan.

El texto presenta algunas variantes de interés en las dos voces restantes ${ }^{11}$.

\section{Aspectos formales}

A simple vista se observa que se trata de una ensalada breve y sencilla, cuya estructura literariomusical voy a analizar ahora someramente. Debajo del epígrafe «Ensalada a 3» figura el siguiente texto en el manuscrito:

$$
\begin{aligned}
& \text { "Todas las demás coplas } \\
& \text { que están al fin de la } \\
& \text { ensalada van por la } \\
& \text { música desta primera." }
\end{aligned}
$$

Según esta indicación, la música correspondiente a los versos 1 al 4, que, aunque en la parte musical no consta específicamente como «Copla», deberá repetirse para cada una de las estrofas de cuatro versos (excepto la última que es de ocho: versos 69 al 76) y que he señalado convencionalmente con números romanos entre claudátur. Lo que sí indica el manuscrito dentro de la música es la «Copla» del estribillo, con lo cual tenemos que cada estrofa consta de las siguientes partes:

$A=$ copla de cuatro versos (excepto la de la V que tiene ocho); con la misma música para todas.

$\mathrm{B}=$ estribillo de cuatro versos (excepto el de la II cuyas interjecciones separo por cuestiones de rima, y el de la V que consta sólo de los dos de la cancioncilla tradicional); cada uno con su propia música.

11. Se dan en los siguientes versos:

$\begin{array}{lll}1 \text { avierto } & 35 \text { eys / o } & 59 \mathrm{si} \\ 13 \text { Creedlo / Creeldo } & 42 \text { dejas } & 67 \mathrm{si} \\ 22 \text { non } & 44 \text { renta } & 77 \text { villano } \\ 25 \text { eys / o } & 45 \text { te } & 81 \text { aiudándonos } \\ 28 \text { e } & 46 \text { debieras } & 86 \text { faysán } \\ 30 \text { naon } & 52 \text { renta } & 87 \text { villano }\end{array}$


$\mathrm{C}=$ copla del estribillo de cuatro versos (excepto la de la V que tiene ocho); cada una con su propia música. Conviene señalar que la música de la copla del estribillo final está inspirada en él mismo, obedeciendo, quizás, a una intención conclusiva premeditada.

$\mathrm{B}=$ repetición del estribillo, no siempre literalmente sino con algunas variantes (dos versos diferentes en las estrofas I, II y III; y ;O! por ;Ay! en la IV); la música no varía en estas repeticiones.

Esta esquemática tipología formal permite a poeta y músico planificar la pieza en un todo orgánico, perfectamente coherente con el discurso narrativo del texto. Así, la música de cada redondilla inicial, al ser siempre la misma, actúa a guisa de motivo vertebrador, y también como carta de presentación de cada personaje que comparece en audiencia ante este Rey no terrenal. El poeta adopta aquí un tono serio con la inclusión de elementos característicos del género «romance», en lo que se refiere a la exposición de los sucesos y a su intención dialogante; el músico, por su parte, atrae la atención del oyente utilizando el estilo homofónico, casi en tono declamatorio, para hacer perfectamente inteligible el texto y secundar la verosimilitud de la historia.

Los estribillos, de carácter popular, llegan vivos procedentes de la tradición oral: conservan todavía la «cabeza» o «núcleo», ese punto de arranque lírico y de ingenuo vuelo poético, de temática profana, las más de las veces, conteniendo un tema de moda, o incluso un refrán de amplia difusión, que el poeta, en este caso, contrahace a lo divino. Cuando este estribillo, procedente de tiempos anteriores a la época que nos ocupa (entronque de los siglos XVI y XVII), ha perdido las estrofas o grupos versificados que lo desarrollaban - y que junto con él constituían el villancico propiamente dicho-, el poeta divinizador se ve obligado a inventar otras estrofas, adaptándolas al punto de vista ideológico que le interesa. Surge así la «glosa», que es un desarrollo culto que utiliza como pretexto un villancico o estribillo popular para explicar convenientemente lo insinuado en él, y que después será retomado para coronar la estrofa. La música se ciñe también a esta nueva situación: si bien mantiene la concisión de la homofonía, no descarta recurrir al artificio del contrapunto imitativo, tanto como simple elemento de contraste como para aligerar con fluidez el discurso polifónico y la carga semántica del texto.

Los anteriores aspectos formales se condensan en la presente pieza siguiendo una estructura de menor a mayor complejidad, que se podría resumir de la siguiente manera: cinco villancicos con sus estribillos tradicionales y sus correspondientes coplas engarzados mediante un planteamiento típico del romance y que desembocan en el marco de una ensalada «a lo divino», con sus convencionalismos característicos de libertad métrica, estrofismo variado, carácter dialogante de los diversos personajes y plurilingüismo.

En esta composición se observan, además, tres grandes secciones semejantes a los tres actos de cualquier comedia de la época (planteamiento, nudo y desenlace), como recogía Lope de Vega en su tratado El arte nuevo de hacer comedias en este tiempo, (ed. de 1613):

"En el acto primero ponga el caso,

En el segundo enlaze los sucessos 
De suerte q[ue], hasta el medio del tercero,

Apenas juzgue nadie en lo que para." 12

Así, los cuatro primeros versos serían una especie de presentación o introducción de la «audiencia» que el Rey concede; seguiría después el desarrollo propiamente dicho de la ensalada con el desfile de diferentes personajes alegando o solicitando al Rey cada cual lo suyo, y que llegaría hasta el verso 68; a partir de aquí entraríamos en el desenlace, en el que los villanos satisfacen su impuesto y dan gracias a Dios por los frutos de la tierra.

Ésta es, grosso modo, la forma externa de la pieza ${ }^{13}$, en la que texto y música participan por igual de un mismo ideario estético y de idéntico poder de comunicación; otra cosa será su capacidad alegórica o simbólica, su línea argumental y su relación con el contexto social y cultural, aspectos de los que vamos a tratar a continuación.

\section{Comentarios}

Como podemos observar en las ensaladas del siglo XVI que se nos han conservado, la mayoría de ellas teníćn, en un principio, como finalidad la de cantar el misterio de la Natividad. Posteriormente, la propia evolución de este género literariomusical en contacto con las condiciones ideológicas y sociales de la época facilitó su cambio de orientación que pasó de la temática navideña a la eucarística. En este sentido, tanto Josep Romeu Figueras como Bruce W. Wardropper han estudiado ya esta circunstancia y a sus escritos remito al lector ${ }^{14}$.

Estamos, pues, ante una ensalada de argumento eucarístico, que contrahace «a lo divino» una cancioncilla tradicional muy en boga en los siglos XVI y XVII:

"Al villano se lo dan

la cebolla con el pan. 15,

12. Lope de VEGA, El arte nuevo de hacer comedias en este tiempo, edición y estudio preliminar de Juana de José Prades, Madrid, Consejo Superior de Investigaciones Científicas, 1971; transcribo literalmente los vv. 293-301, p. 297.

13. Vid. al respecto los siguientes textos: José RomeU Figueras, "La poesía popular en los Cancioneros Musicales españoles de los siglos XV y XVI", Anuario Musical, IV (1949), pp. 83-84. José Romeu Figueras, "Mateo Flecha el Viejo, la corte...", passim. Bruce W. WARDROPPER, Historia de la poesía lírica a lo divino en la Cristiandad occidental, Madrid, Revista de Occidente, 1958, p. 184 y ss. Margit Frenk Alatorre, Estudios sobre lírica..., pp. 69-73 y 246 y ss.

14. José Romeu Figueras, "Las canciones de raíz tradicional acogidas por Cárceres en su ensalada «La trulla»", Miscelánea en homenaje a monseñor Higinio Anglés, vol. II, Barcelona, C.S.I.C., 1958-61, pp. 735-768; dice en la p. 742: "Cárceres, Vila, Chacón y Flecha el Joven son los cuatro discípulos del gran polifonista [se refiere a Mateo Flecha el Viejo] representados en la edición de Praga, como hemos indicado. Vila sigue al maestro con menos originalidad que sus compañeros, imitándole con evidente fidelidad. En cambio, Chacón y Flecha el Joven son más innovadores, por cuanto convierten la ensalada navideña en eucarística al enlazar el misterio de la Encarnación, presentando bajo símbolos que el poeta procura interpretar, con el del Sacramento, envuelto en parecido ropaje simbólico y tratado con el mismo afán interpretador. Chacón, al subrayar en su ensalada que 'todo es aquí Sacramento', y Flecha el Joven al aludir en la suya al 'Pan de vida', dan paso a la corriente eucarística en la ensalada. De esta forma ambos se muestran sensibles a la poderosa tendencia hispana que, ya hacia 1520, había motivado la conversión del teatro navideño, precisamente, en teatro eucarístico, dando así un paso considerable en el proceso de formación del auto sacramental español". El propio Romeu cita, asimismo, en nota a pie de página el libro de Bruce W. WARDROPPER, Introducción al teatro religioso del Siglo de Oro. (Evolución del Auto Sacramental: 1500-1648), Madrid, Revista de Occidente, 1953, diciendo que "contiene notables precisiones y juicios sobre el paso del teatro navideño al sacramental,"

15. Son muy numerosas las fuentes literarias, y musicales (vocales e instrumentales), que contienen este popularísimo estribillo. En las obras que cito a continuación pueden rastrearse sus diferentes versiones y procedencias: Noël SALOMON, Lo villano 
El contrafactum, sin duda debido a una mano culta, está muy logrado en su simplicidad y consigue unir perfectamente el sabor rústico o pastoril con la intención religiosa:

"Al villano se la dan

la ventura con el pan."

En efecto, sin variar el metro ni la rima, el poeta divinizador conseguía de pleno una honda significación alegórica con tan sólo cambiar una palabra (cebolla), que designaba un alimento para el cuerpo, por otra (ventura), que hacía referencia a un alimento para el alma. Con esta capacidad de asociación y de analogía que sustituía el sentido profano por otro sagrado, este pan terrenal devenía en pan eucarístico, y a través de una ingeniosidad como ésta, perfectamente comprensible para el espectador normal imbuido del espíritu contrarreformista de la época, el impacto en las gentes estaba asegurado y con ello su propósito de instruirlas en la fe católica. No interesaba, en ese momento y lugar concretos, la explicación del misterio de la Eucaristía mediante inasequibles conceptos teológicos, sino simplemente su amplia difusión a través de alegorías tomadas de la vida cotidiana; entre otras razones porque convenía diferenciar la postura heterodoxa del teólogo, y del místico, — que con su simbología particular trascendían el misterio y lo investigaban intelectualmente-, de la actitud tan distinta del poeta contrafactista que, mediante la alegoría — como método concreto de vulgarización espiritual-, aceptaba sin rechistar ese mismo misterio y lo exponía, manoseado y falto de autenticidad, a la comprensión fanática e irracional de las masas. El teólogo y el místico dudaban; el divinizador no, y, evidentemente, tampoco hacía dudar al pueblo ${ }^{17}$. La presente ensalada cumplía, pues, con la intención tridentina de propaganda fide, y también, por otro lado, con la máxima del Deleitar aprovechando, que refería concisamente el sentir de los dramaturgos del Siglo de Oro y la doble intencionalidad, lúdica y didáctica, de su teatro y formas literarias afines o asimilables.

Por otra parte, el villano, analfabeto en su mayoría - pero no hasta tal extremo de ignorancia que no comprendiera perfectamente los recursos y convencionalismos del lenguaje poético de su época, apoyado en una rica tradición oral—, se sentía cómodo en una religión como la cristiana, que le sosegaba de su inquietud ante la vida ultramundana y le acercaba a lo inefable,

en el teatro del Siglo de Oro, Madrid, Editorial Castalia, 1985, pp. 525-527. Margit Frenk, Corpus..., pp. 739-741; vid. también de la misma autora y obra, el Suplemento, (mismo lugar y ed.), 1992, p. 38. Estas magníficas recopilaciones de Frenk son de suma utilidad, ya que reseñan, en una bibliografía muy completa, tanto las fuentes de primera mano como las antologías, cancioneros, libros y artículos a los que esta estudiosa ha tenido acceso y que me exime a mí de citarlos uno por uno.

16. También abundan las fuentes que recogen este tema divinizado; vid. al respecto: Noël SALOMON, op. cit., pp. 528-530. Margit FrENK, Corpus..., pp. 739-741, y su Suplemento, p. 38. Bruce W. WARDROPPER, Historia de la poesía lírica a lo divino..., pp. 211-218. Y, además, José de VAldivielso, Romancero espiritual, edición, introducción y notas de J. M. AGUIRRE, EspasaCalpe, Madrid, 1984, pp. 253-254. En algunas de estas fuentes, así como las que recogen la canción lírica profana, se contempla también la supervivencia del tema del villano hasta el folklore actual. Vid, asimismo, de Miguel Querol el artículo citado anteriormente, "El villano de la época de Cervantes...", el libro La música en las obras de Cervantes, Barcelona, Ediciones Comtalia, 1948, y una transcripción musical del estribillo de la presente ensalada, en La música en las obras de Cervantes. Romances, canciones y danzas tradicionales a tres y cuatro voces y para canto y piano, Madrid, Unión Musical Española, 1971, pp. 9-10.

17. Cfr. Bruce W. WARDROPPER, Historia de la poesía lírica a lo divino..., especialmente el capítulo XIII: "Significación espiritual y literaria de los Contrafacta", pp. 319-332. Sobre el fenómeno de la poesía a lo divino en España vid. J. M. AguiRRE, José de Valdivielso y la poesía religiosa tradicional, Toledo, Diputación Provincial, 1965, sobre todo el capítulo III, pp. 41-89. 
mediante una forma artística, poética y musical, al alcance de su mentalidad simple, y, sin duda, mucho más efectiva que la teología dogmática. Los autores anónimos de esta obra se ocupaban primero de sus aspectos artísticos, de llegar al oyente por vía sensitiva; inmediatamente después, con la profundidad metafísica de la alegoría lograban interpretar todo un universo espiritual a partir de situaciones de la vida mundana; por último, como efecto de simpatía, venía la imposición dogmática que había de penetrar así mucho mejor en el ánimo del vulgo, y con mayor vivacidad.

La ensalada se inicia con la narración, dirigida a $\mathrm{Gil}^{18}$ —nombre especialmente acuñado para designar a un pastor no exento de cierta comicidad, y que se erige en paradigma de personaje rústico y convencional-, de una audiencia que solicitan ciertos personajes, también convencionales, los cuales comparecerán ante un Rey — alegoría de Cristo Sacramentado— que se halla cubierto, es decir, guardado y depositado en el sagrario o protegido en la custodia. La audiencia siempre es un don concedido por un rey terrenal que se celebra ante un consejo o tribunal, y del que hallamos un bello ejemplo vuelto a lo divino en los Elogios de Valdivielso: "Cristo es «Rey que a todos concede grata audiencia»" $"$.

En el primer estribillo (vv. 5 a 8), y su correspondiente copla (vv. 9 a 16), observamos ya el carácter dialogante del texto, tan característico de las ensaladas y ensaladillas, entre un personaje indeterminado (¿un villano?) y un sacristán portugués; este último prolongará su actuación durante el estribillo (vv. 21 a 26) y la copla (vv. 27 a 36), pertenecientes al II grupo versificado.

"Sentenciad" tiene aquí el sentido de expresar juicio o dictamen que se requiere al Rey para que decida entre el incrédulo y escéptico personaje ("Yo dije: -Comedlo [variante: 'creedlo'] vos, que pan solamente vi...") y el portugués que canta las excelencias de su condición social hidalga y las del trigo de Portugal. Hay varios puntos a comentar aquí. En primer lugar, la posición del incrédulo no es tan radical como parece, ya que él mismo reconoce que, al haber probado un único bocado de ese pan (Eucaristía), su alma ha quedado suspendida, en posesión de la divinidad, ("me tiene muerto, por Dios") y por tanto, a partir de ese momento, puede decirse que ya cree, aunque no sepa por qué. Posiblemente se trate de una vulgarización de la secuencia «Lauda Sion» de Santo Tomás de Aquino (concretamente de los versos «Quod non capis, quod

18. "Este nombre en lengua castellana, es muy apropiado a los çagales y pastores en la poesía", dice CovARRUBIAS en su Tesoro..., p. 639 b. Sobre la utilización alegórica de este nombre o personaje con fines moralistas en la tradición literaria anterior, vid. algunas notas en Juan del Encina, Obras completas, IV. Teatro, edición, introducción y notas de Ana María Rambaldo, Madrid, Espasa-Calpe, 1983, pp. XVIII-XIX. Vid., por otra parte, Noël SALOMoN, op. cit., p. 353, nota 15, donde cita el Cancionero de Ubeda y diversas obras de Alonso de Bonilla, Juan López Timoneda, Alonso de Ledesma y José de Valdivielso que hacen referencia a "la moda de los coloquios pastoriles a lo divino" entre Gil y otros personajes.

19. Recogido en José de VAldivielso, op. cit., p. 87, donde se incluye el "Romance al Santíssimo Sacramento, en metáfora de una audiencia que da su Magestad". Vid también la Conversión de la Magdalena, de Malón de CHAIDE, donde "a Dios Padre, en las Cortes del Cielo, le vemos bajo el disfraz de «un Procurador justísimo»", apud Bruce W. WARDROPPER, Historia de la poesía lírica a lo divino..., p. 10. 
non vides, / animosa firmat fides / præter rerum ordinem»), como señala J. M. Aguirre en un ejemplo del Maestro Valdivielso ${ }^{20}$.

El sacristán portugués es un personaje conocido en muchas ensaladas y ensaladillas de la época, y, como aquí, suele expresarse con su peculiar orgullo y en su propia lengua, a veces, en una jerga difícil de entender" ${ }^{21}$. Ante la audiencia lo vemos ahora alardeando de su hidalguía ("So muyto fidalgo"), en contraposición a la tosquedad del personaje al que intenta "hazer encreyentes", y que en su falta de luces sólo cree aquello que ve. Al igual que la comedia de ambiente rústico, este fragmento de la ensalada recoge fielmente, entre bromas y veras, y también como inocente pasatiempo, algunas de las características más acusadas de la ideología aristocrática. Mediante acentos didácticos, y de la misma manera que en cualquier espectáculo teatral —pongamos por caso, un auto sacramental, "género que representaba la más completa síntesis de las artes y del pensamiento teológico contrarreformista" "22 , y que Calderón habría de definir más tarde como "sermón en representable idea"-, la presente ensalada refleja aspectos relacionados con la realidad vivencial del momento, entre los que se observan la diferencia de estamentos en la sociedad española monárquico-señorial de la época ${ }^{23}$, y la proverbial burla y escarnio que se hacía del villano en medios urbanos, más dado a satisfacer sus necesidades primarias en el comer, beber y dormir, que no a discurrir sobre la presencia de Dios en la tierra. En el fondo de la cuestión está la sempiterna lucha entre los instintos fisiológicos, encarnados por el villano, y las motivaciones del espíritu que mueven al sacristán, que "a par de Dios se ponía." Con las exclamaciones "ollay"

20. Cfr. José de VAldivielso, op. cit., p. 36, donde se halla un "Diálogo al Santíssimo Sacramento" entre Gil y Bras. He aquí un fragmento que nos interesa:

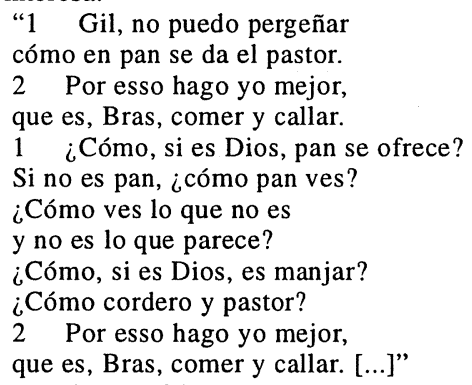

21. Prueba de ello es el verso 24, que es un enigma y me obliga a moverme en el terreno de las conjeturas: adela puede referirse a una actividad femenina antigua de carácter celestinesco o de comadreo; la expresión completa, voto adela, tendría, pues, una intención chistosa y disparatada, algo irreverente si se quiere, pero quizás no tan alejada del espíritu de la pieza. También cabe interpretar dela, con lo cual se daría cierto paralelismo con otras imprecaciones o blasfemias de tipo eufemístico como diola, diolo, diosle, que aún hoy perduran en el lenguaje popular de ciertas áreas peninsulares. Finalmente, y ésta sí me parece una conjetura traída por los pelos, el poeta podría haber escrito e pan, bento demais (el pan, bendito además); bento, por vacilación de b en $\mathrm{v}$, da vento, y si el copista no está muy versado en lengua portuguesa o no entiende el texto puede hacer, lo que en crítica textual se llama una lectio facilior, y escribir lo que primero le venga a la mente atendiendo a la similitud gráfica, que sin duda existe. En todo caso tropezaríamos aquí también con el problema de la rima. En relación al bilingüismo castellano/portugués y al uso de esta última como lengua cómica, vid. Rainer Hess, El drama religioso románico como comedia religiosa y profana, (siglos XV y XVI), Madrid, Gredos, 1976, pp. 116-117.

22. Emilio Orozco Díaz, Manierismo y barroco, Madrid, Ediciones Cátedra, 1988, (4ª ed.), p. 49.

23. Cfr. Noël Salomon, op. cit., p. 66: "Para los ciudadanos españoles de fines del siglo XVI y principios del siglo XVII - muchos eran nobles y dueños de tierras y vasallos - el villano seguía siendo en lo hondo, un ser inferior y ridículo, según el concepto plasmado desde siglos atrás por el prejuicio feudal. Las capas sociales bajas de la población urbana, así como la clase media de los hidalgos ciudadanos o quienes pretendían a la hidalguía, eran partícipes de este estado de espíritu." 
(ved, mirad) y “¡ay!”, el portugués quiere resaltar la bondad del trigo de Portugal, según él, de mejor calidad que el de Castilla, sobre todo, para la elaboración de ese "pan mays celestial". No deja de ser curioso que Valdivielso también vituperara el trigo de la Mancha en varias de sus poesías, quizás por una connotación semántica con la mancha del pecado original ${ }^{24}$.

El siguiente personaje que introduce el narrador es también un tópico convencional en la literatura de la época (vv. 37 a 52). Se trata del vizcaíno, sin duda, "un hombre de buena ley" que se presenta ante esta audiencia sin circunloquios innecesarios, sino "acortando razones", y utilizando su castellano estropeado, lleno de concordancias vizcaínas, que hace que "no le entendiera el Rey", sino entendiera a los hombres de carácter franco y noble. La ensalada es un género en el que la parodia y el humor se usan con frecuencia para provocar la risa fácil; el vizcaíno se prestaba magníficamente a ello, por su jerigonza habitual que trastoca la morfología y el orden sintáctico de las frases, y aun su sentido, que raya en el disparate ${ }^{25}$. Ciertamente, me es bastante difícil comprender el significado exacto de estos versos, a medio camino entre lo sacro y lo profano, lo serio y lo cómico, y quizás con ciertos matices de sátira política. "Servicios" lo podemos entender tanto como "el rendimiento y culto que se debe a Dios" como "la porción de comienza así:

24. José de Valdivielso, op. cit., p. 82. Vid. el "Romance a Nuestra Señora con el Niño Iesús en sus braços", que

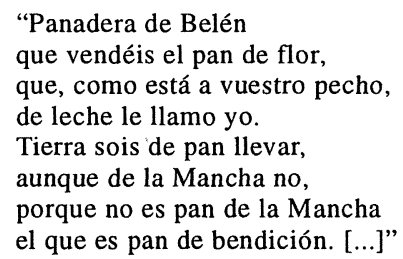

Y en la p. 142 figura una "Letra. Diálogo", uno de cuyos fragmentos me interesa especialmente:

"1 Nuevas de groria infinita traigo, Antón, el pecho ensancha,

25. Enseguida viene a la memoria el célebre «Don Sancho de Azpeitia» cervantino en su lucha con Don Quijote ( $1^{\mathrm{a}}$ parte, capítulos VIII-IX), o el personaje de Quiñones en el entremés El vizcaíno fingido, también de Cervantes. Vid. además Francisco INDURÁIN, "El tema de vizcaíno en Cervantes", Anales Cervantinos, (1951), pp. 337-343; en especial la p. 339, donde dice: “...el tipo de vizcaíno era un personaje de carácter cómico, muy familiar a público y autores del teatro prelopesco, que proporcionaba un fácil recurso de risa con su habla peculiar, de la misma manera que los negros, portugueses, moriscos, rufianes, pastores y gitanas o frailes zaceadores. El popularismo del teatro de entonces era campo abonado para un truco de comicidad tan ingenua como eficaz [...] ." Por su parte, Noël SAlomon, op. cit., p. 60, refiere que "existe una variante de los sentimientos antivillanos que aparecieron en el siglo XVI, en la época de las migraciones provinciales en dirección de las grandes ciudades castellanas, bajo forma de una burla del ciudadano hacia el rústico llegado de lejos, especialmente si es gallego o vizcaíno. Son frecuentes las bromas a cuenta de estos villanos provincianos, mal desbastados [...]." Por último, cito algunos versos de la ensalada que incluye DíAz RENGIFo en su tratado (vid. nota 3) y observamos también, como en la nuestra, la presteza que se da el vizcaíno en echar mano a su machete:

\author{
“[...] Vizcaíno sabio \\ piloto llevar. \\ Golfo de las Yeguas \\ andado le tienes, \\ Cabo de Esperança \\ seguro le vienes, \\ si cosario sales \\ machete sacar. \\ Vizcaíno sabio etc. [...]"
}


dinero ofrecida voluntariamente al Rey" (Diccionario de Autoridades); "blanca" es una "moneda menuda", de poco valor, pero también es el "manjar blanco, [...] plato de españoles" (Covarrubias, Tesoro...), aunque aquí posiblemente se refiera a la sagrada forma. La "rrenta" es una ganancia terrenal y temporal que, entendida a lo divino, puede significar la asunción de la gracia o bienes espirituales $^{26}$. Los vv. 45-48 recuerdan el pasaje del apresamiento de Jesús, en el que Simón Pedro hirió de la misma manera a Malco, siervo de Caifás (San Juan, XVIII, 10).

El grupo versificado IV (vv. 53 a 68) recoge la intervención en la audiencia de una gitana que, con su habitual zalamería, intenta "sacarle una blanca" al Rey a cambio de decirle la buenaventura $^{27}$. Al contrario de lo que se suele deducir de la literatura de la época, la gitana de esta ensalada no parece sufrir el escarnio y el rechazo social que era normal para con los de su clase, vituperada hasta la saciedad por su tendencia a la vida pícara, al hurto y al engaño ${ }^{28}$. El estribillo (vv. 57 a 60), con el ceceo típico de los gitanos, es de una belleza lírica cautivadora, y ha merecido la inclusión en el Corpus... de Margit Frenk, a partir de esta única fuente que tratamos $^{29}$. Además, la glosa (vv. 61 a 64), con sus oraciones yuxtapuestas, que tan bien reflejan dicen así:

26. Cfr. con un "Villancico al Santíssimo Sacramento" de José de VAldivielso, op. cit., p. 34, cuyos primeros versos

$$
\begin{aligned}
& \text { "Un señor de gran poder, } \\
& \text { porque vivan descansados, } \\
& \text { ha dexado a sus criados } \\
& \text { por la Iglesia de comer. } \\
& \text { Por la Santa Iglesia tienen } \\
& \text { renta de vino y de pan, } \\
& \text { mas dizen que se lo dan } \\
& \text { con que primero se ordenen; } \\
& \text { bien puestos los quiere ver, } \\
& \text { y, por verlos descansados, } \\
& \text { ha dexado a sus criados } \\
& \text { por la Iglesia qué comer." }
\end{aligned}
$$

27. Carmen Bravo-Villasante, en su introducción y edición de Villancicos del siglo XVII y XVIII, Madrid, Ed. Magisterio Español, 1978, pp. 16-19 y 60-62, incluye un villancico al Nacimiento (1694) que "finaliza con un nocturno gitano en que las gitanas y gitanos bailan la zambra y cantan muy graciosamente con profusión de zetas andaluzas, y hasta echan la buenaventura al Niño, a la manera de la misa flamenca." Me interesa especialmente el estribillo, que es una variante del que nos ocupa:

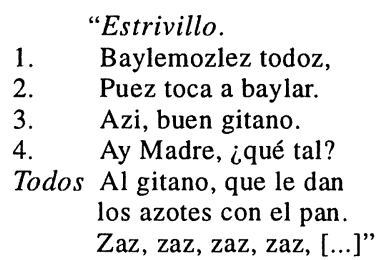

Otra variante viene citada por Bruce W. WARDROPPER, Historia de la poesía lírica a lo divino..., p. 217; se trata de "una mojiganga anónima de hacia 1670, la de la Gitanada, [en la cual] se baila un villano sacramental:

Hoy al hombre se lo dan carne y sangre, vino y pan."

28. Cfr. Miguel de Cervantes SaAvedra, Novelas Ejemplares I, La gitanilla, edición de Harry Sieber, Madrid, Ediciones Cátedra, 1992, p. 61: "Parece que los gitanos y gitanas solamente nacieron en el mundo para ser ladrones: nacen de padres ladrones, críanse con ladrones, estudian para ladrones, y, finalmente, salen con ser ladrones corrientes y molientes a todo ruedo, y la gana del hurtar y el hurtar son en ellos como ac[c]identes inseparables, que no se quitan sino con la muerte." que dice

29. Margit Frenk, Corpus..., p. 614. Este estribillo recuerda también a la despabilada Preciosa cervantina en aquel pasaje

“- $[\ldots]$ ¿Sabes decir la buenaventura, niña? 
el sentido engatusador de la buenaventura, resulta candorosa en su simplicidad y se adapta perfectamente al estribillo.

Estamos ya en el último grupo versificado de la pieza (vv. 69 a 88), posiblemente el de mayor ambición poética de toda la ensalada. Los villanos se presentan "al Rey de hecho" en el consejo con la intención de "pagarle el pecho", o sea, "cierto tributo que se da al rey" (Covarrubias, Tesoro...), en este caso sobre el trigo, y del que, a diferencia de los hidalgos, no estaban exentos. Estos cantos ejecutados por los villanos - a buen seguro cantantes disfrazados de rústicos y metiendo bulla ${ }^{30}$ - traen origen y carácter popular en su inmensa mayoría y encuentran en las representaciones teatrales su nivel de máxima aplicación, siempre dignificados y puestos en escena convenientemente por la mano del dramaturgo y adornados polifónicamente por la del músico. De hecho, hay que buscar su procedencia en la diversidad de fiestas aldeanas que jalonaban los ciclos vitales de las gentes del campo: ya fueran festejos profanos que acompañaban las tareas agrícolas (entendamos generosamente el verso 80, "porque sembrando en el suelo") o que culminaban la siega (asimismo, el verso 82 con tintes a lo divino, "mucho pan al fin cogimos"); ya fueran celebraciones religiosas como bodas, bautizos o cualquier otro tipo de festividad local. En todas ellas, los villanos cantaban y bailaban sirviéndose incluso del acompañamiento de instrumentos musicales; y no faltarían tampoco las danzas cantadas con saltos y brincos que alegrarían las canciones, confiriéndoles así su marcado carácter campesino. Será a partir de 1580 cuando estos motivos o elementos populares, insertados ahora comúnmente en el cómodo epígrafe de la «lírica musical de tipo popular o tradicional», pasarán a formar parte principal del teatro, es decir, de la comedia, del auto sacramental, del entremés y del «baile» ${ }^{31}$. Por esta razón tampoco se puede desestimar la posibilidad de que la presente ensalada se cantara en algún entremés de carácter religioso, puesto que ni siquiera en los autos sacranentales se rechazaba el concurso de los entremeses cuando así convenía, ya que, de hecho, tanto la situación cómica, la humorada y la risa, como el canto ("cantaron en su presencia"), el baile final ("baylando con eminencia") y los personajes arquetípicos (el sacristán, el vizcaíno y la gitana) allí se corresponden y tienen cabida. Por eso resulta tan difícil saber con exactitud en qué tipo de representación o de fiesta podría interpretarse esta ensalada ${ }^{32}$; quizá en una representación moral o en una loa sacramental ${ }^{33}$.

-De tres o cuatro maneras - respondió Preciosa.

- ¿Y eso más? - dijo doña Clara. Por vida del tiniente, mi señor, que me la has de decir, niña de oro, y niña de plata [...]." Cervantes, Novelas Ejemplares..., pp. 77-78.

30. Dice Noël Salomon al respecto en op. cit., p. 473: "Sabemos que los villanos y los segadores que cantaban a veces no eran sino los mismos músicos disfrazados de villanos y segadores. Entonces podía surgir la tentación de dar rienda suelta a los recursos vocales e instrumentales."

31. Cfr. Margit Frenk Alatorre, Estudios sobre lírica..., pp. 77-78; también Noël Salomon, op. cit., p. 368 y ss.

32. También es posible que se cantara en las paradas de la procesión del Corpus, o en las «cuarenta horas» de adoración perpetua al Santísimo Sacramento, o en alguna «siesta». Por otra parte, Jaime Moll, en su artículo "Libros de música e instrumentos musicales de la princesa Juana de Austria", Anuario Musical, XX (1965), p. 18, señala que "En la corte real era frecuente intercalar alguna ensalada entre los villancicos, aún a fines del siglo XVI y principios del XVII." Vid., también, Juan CARRILLO, Relación histórica de la Real Fundación del Monasterio de las Descalzas de S. Clara de la villa de Madrid, Madrid, Luis Sánchez, 1616, f. 35v-38v, citado por Rafael Mota Murillo en Sebastián LoPez DE Velasco (1584-1659), Libro de missas, motetes, salmos, magnificats y otras cosas tocantes al culto divino, vol. I, Madrid, Sociedad Española de Musicología, pp. 155-156.

33. Vid. la Colección de entremeses, loas, bailes, jácaras y mojigangas desde fines del siglo XVI a mediados del 
En realidad, lo que debe importar aquí es que, en la época barroca, se teatraliza hasta tal extremo la vida toda que, incluso, en las fiestas religiosas como los autos sacramentales está presente el influjo de algunas facetas del teatro profano: por ejemplo, en la disposición escénica del presbiterio y del̉ retablo, en la actitud del predicador que imita la gesticulación del comediante, en el uso común de cantos y danzas, etc. Con razón ha podido decir Emilio Orozco que "el templo se concibe con sentido paralelo a la escena para cumplir, a lo divino, la función social que en lo mundano realiza el teatro" ${ }^{, 34}$. Y es que en las características tan barrocas de aparatosidad y atracción sensorial subyace la idea capital de este movimiento ideológico y artístico y que no es otra que la del desengaño existencial, que se observa en la hiperbolización de la apariencia opuesta a la realidad, en la exuberancia de la forma exterior enfrentada al contenido, en aquello que, en definitiva, dotará a la vida terrenal de un inevitable carácter de vanidad y superficialidad. Si se vive con tanta pasión el teatro y se representa dramáticamente la vida cotidiana, no es de extrañar que el Segismundo calderoniano desconfíe de la realidad aparente y llegue a creer que La vida es sueño y que el propio Calderón, más tarde, compare la vida con El gran teatro del mundo y consiga llevar a la escena, en el momento culminante del barroquismo, el teatro dentro del teatro.

Prosiguiendo con nuestra ensalada, vemos, pues, que su carácter escénico se pone aún más de manifiesto cuando todos juntos cantan y bailan un villano ante el Rey ${ }^{35}$. El villano es un "tañido de la danza española, llamado assí, porque sus movimientos son a semejanza de los bailes de los aldeanos" (Diccionario de Autoridades ). Conviene recordar la diferencia que había, sobre todo en el plano moral, entre baile y danza: el baile era de corte más popular, con movimientos

XVIII, ordenada por Emilio Cotarelo y Mori, Madrid, Casa Editorial Bailley / Bailliére, 1991, [Nueva Biblioteca de Autores Españoles, 17-18]. En los dos volúmenes de esta obra son muchas las piezas de todo tipo que presentan claras analogías de temática, forma y contenido con la ensalada que estudiamos; sin embargo, no he podido encontrarla ahí. Quizás nuestra ensalada fue una vulgarización de una obra poética de mayor alcance artístico, y no se le dio la debida importancia en su momento. También hay que tener en cuenta que han sido enormes las pérdidas de poesías del Siglo de Oro que hemos sufrido a través del tiempo, y no sería de extrañar que nunca lleguemos a saber si esta ensalada procede de una fuente literaria concreta, o si fue producto de creación efímera y exclusiva para su música.

34. Emilio Orozco Díaz, Introducción al Barroco, I, Granada, Universidad de Granada, 1988, p. 269.

35. Sobre algunos aspectos de la danza del villano, vid. Juan José ReY, Danzas cantadas en el Renacimiento español, Madrid, Sociedad Española de Musicología, 1978, pp. 22-24. Este musicólogo transcribe los fragmentos del tratado de Francisco S ALINAS, De musica libri septem, (Salamanca, 1592), que hacen referencia a la danza del villano. Vid. también la primera versión castellana del célebre tratado realizada por Ismael FERNÁNDEZ DE LA CUESTA a partir de la edición de Salamanca (1577): Francisco Salinas, Siete libros sobre la música, Madrid, Ed. Alpuerto, 1983, p. 514, donde dice: "Según este metro, [se refiere al pirriquio] y según estos modos, está compuesto el canto llamado en España villano, porque la gente de las villas y del campo suelen danzar con él más que con otros". Algunos estudiosos citan esta edición de 1577 como la fuente más temprana que contiene el estribillo tradicional "Al villano se lo dan / la ventura con el pan"; sin embargo, no lo he hallado allí, ni tampoco Margit FRENK, según manifiesta en su Corpus..., p. 739. Por las connotaciones textuales que presenta con algunos fragmentos de nuestra ensalada, vid. también Juan Bautista Comes, Danzas del Santísimo Corpus Christi, transcripción realizada por D. Vicente GARCía Julbe. Valencia, Diputación Provincial de Valencia, 1952; el pasaje que me interesa está en las pp. 1-3 de la parte musical, corresponde al "Principio de las danças en el altar. A 4 dançado", y es el siguiente:

"Dame la mano zagal

y haziendo una reverencia, canta y bayla en la presencia de aqueste Pan celestial."

En relación a la supervivencia de la danza del villano en el folklore actual, vid. el artículo de Angel Vergara MiRAVETE, "Supervivencia de formas de danza antigua en las músicas del dance aragonés", Nassarre. Revista aragonesa de Musicología, VI, 1 (1990), pp. 179-192. 
indecorosos y obscenos las más de las veces, que molestaban al espectador pudoroso y merecían el repudio de los detractores del teatro; la danza, más refinada, contaba con la aprobación de las personas virtuosas, y los censores la admitían porque animaba la representación dentro de los límites del recato y del decoro ${ }^{36}$. Hemos visto como en la España de los siglos XVI y XVII se divinizaba la poesía lírica popular; pero también los bailes referidos en ella, que surgían en comedias, entremeses y ensaladas, sufrían idéntico proceso, cuando así se estipulaba. Bruce W. Wardropper establece un acertado paralelismo entre baile y poesía a lo divino, y danza y poesía sacra: "Podemos afirmar — dice— que si las danzas corresponden a la poesía divina original, los bailes son la materia cruda de las divinizaciones, la poesía popular coreográfica" ${ }^{37}$. En la presente ensalada, el baile cantado del villano incluiría sin duda los ingredientes típicos del ambiente teatral y popular de la época: bullicio, animación, concesiones a la extravagancia y alguna que otra mueca esperpéntica a las cosas serias de la vida; como vehículo de expresión cultural, el baile del villano llegó a estar auténticamente de moda en la época que tratamos ${ }^{38}$.

La glosa final (vv. 79 a 88) encierra todo el contenido ideológico de la ensalada y viene a desempeñar el papel de colofón que en otras ensaladas suele correr a cargo de una breve sentencia en latín. El sentido de estos últimos versos gira en torno a la acción de gracias —al parecer, no faltan aquí las alusiones bíblicas tan caras a este tipo de piezas (Génesis, XLVII, 23-26) - , por la buena cosecha obtenida durante el año ("mucho pan al fin cogimos"), al asentimiento de la voluntad divina ("Mas, si Dios quiere y vivimos") y a la renuncia de los bienes materiales de este mundo, en aras de una felicidad ideal e intangible ("más contentos quedaremos / que comiendo de un faisán"). El estribillo final actúa a guisa de moraleja y digamos que sintetiza líricamente el mensaje eucarístico de la ensalada.

También puede ofrecernos otro tipo de lectura el contenido de estos versos finales, si lo hacemos desde el punto de vista de la diferencia de clases y de sus implicaciones sociales. Entre otras cosas, porque creo que es conveniente que el análisis de una estructura histórica determinada abarque la mayor cantidad posible de aspectos de la realidad concreta, y no haga referencia, unívocamente, al contenido artístico de los testimonios literarios, musicales o pictóricos y a las facetas psicológicas que animaban la vida espiritual y religiosa de aquella sociedad y de aquella época. Estamos de acuerdo en que a partir de estos testimonios podemos observar buena parte de las normas de comportamiento que regían las relaciones entre los diversos estamentos que conformaban la pirámide social, pero también es importante no desdeñar —en lo económico, político y social - la imposición ideológica de las fuerzas dominantes (Iglesia, monarquía y clase señorial) y su determinante autoridad sobre las creaciones artísticas y literarias, las cuales, como vehículos de expresión artística y de alienación colectiva, mediatizaban los gustos estéticos de la comunidad que, a su vez y como efecto de contrapeso, deseaba obtener - a través de la labor de los artistas y de sus obras - su particular cosmovisión y una exposición idealizada de su mundo

36. Cfr. Noël Salomon, op. cit., pp. 201-202.

37. Bruce W. WARDROPPER, Historia de la poesía lírica a lo divino..., p. 209.

38. Ibidem, p. 210 : “...los bailes populares que más influencia ejercían en los divinizadores eran el villano, la zarabanda y la chacona -bailes que habían de conocer, una vez domados por los grandes músicos clásicos, una fama internacional duradera." 
interior e imaginativo. El violento énfasis de los aspectos devocionales y penitenciales de lo eclesiástico-religioso en la sociedad barroca, es decir, su aparato exterior y pomposo y no lo auténticamente espiritual e interiorizado, mostraba bien a las claras esa autoconmiseración de los creyentes en sus propios pecados y la confianza depositada en las instituciones religiosas como único medio de hacer llevaderas las injusticias sociales en la vida terrenal y de abrigar esperanzas para la otra vida, más verdadera y equitativa. Ello no quiere decir que la clase pudiente estuviera al margen de la conmoción religiosa postridentina y que utilizara cínicamente la religión como arma arrojadiza para aplacar los movimientos de reivindicación o rebeldía social del pueblo, puesto que, en el fondo, todos los estamentos sociales estaban implicados en una misma situación psicológica de creencia colectiva. Lo que ocurría es que las capas más favorecidas aceptaban de muy buen grado, y mejor fuerza si era necesario, su posición privilegiada en el seno de la sociedad $^{39}$.

Volviendo a los versos que rematan nuestra ensalada, vemos como se exalta aquí la laboriosidad del villano, abocado a sus trabajos agrícolas, sin otra opción que la de vivir sumisamente y posibilitar así el mantenimiento fijo de la estructura estamental de la sociedad; en contrapartida, adivinamos también la ociosidad del noble, del terrateniente y del señor que, con su proverbial terror al trabajo, sobre todo al manual, debían su regalada existencia urbana precisamente al trabajo de aquél. Tanto en la pura realidad como en su reflejo, que es la ficción literaria, el cándido villano quedaba sujeto por partida doble: por una parte, al poder omnímodo de Dios en lo espiritual e intemporal, y, por otra, a la autoridad de la monarquía absolutista en lo terrenal y más próximo ${ }^{40}$. Y este sometimiento ideológico obtenía también su punto de apoyo o su sanción consuetudinaria a expensas de una planificación estética que afectaba y condicionaba la estructura inte gral de la obra y las relaciones entre dramaturgo, músico, actores y público, tanto aristocrático como plebeyo. Digamos que existía un tácito quorum para pasarlo bien todos juntos en el espectáculo y gozar de la escena, de los textos y de la música, pero subyacía también la idea de que cada uno debía ocupar su lugar correspondiente, sin transvases imposibles. De esta manera, lo que por otra parte venía a significar la frontera insuperable - claramente delimitada en la teoría literaria y teatral de la época- entre lo cómico (acciones de la vida cotidiana, sentimiento de actualidad, lenguaje y conceptos vulgares) y lo trágico (acción noble, sentimientos elevados y lenguaje esmerado), transcendía, asimismo, hacia la distinción de los estamentos sociales, situación ésta muy bien entendida y defendida por los comentaristas aristotélicos. Se trataba, en suma, de respetar estéticamente el orden social establecido.

La dialéctica entre los aspectos teológicos asumidos por la fe (Rey*como Dios, pan como eucaristía), por una parte, y el ambiente popular y pintoresco (personajes estereotipados, canto y baile aldeanos) y pragmático (pago del tributo real, trabajo en el campo) de la realidad, por otra, viene determinada por la capacidad de transposición alegórico-simbólica que poseen este tipo de composiciones, y que es una de las características esenciales de la actitud barroca. En efecto,

39. Cfr. Emilio Orozco Díaz, Introducción al Barroco..., pp. 251-259.

40. Cfr. Noël Salomon, op. cit., pp. 349-350. 
atraído tanto por la honda y sentida espiritualidad de la ascesis, la desposesión y el misticismo, como por el halago sensorial de la realidad percibida y del hedonismo con que se recrea en la descripción y contemplación de lo aparente, visible y vulgar, el hombre barroco tenderá hacia lo divino y hacia lo humano, y por este doble impulso espiritualizará los aspectos sensibles del cuerpo y de la materia (en nuestra ensalada se da una encarnación de lo divino, puesto que Dios deviene en carne, y la carne en pan que, una vez comido, suspende la vida terrenal, es decir, mata metafórica y realmente; recordemos: "y un bocado que comí / me tiene muerto, por Dios"), y, también como contrapartida, corporeizará y materializará, mediante la alegoría, los aspectos espirituales del alma (la ventura, esa gracia divina, única y verdadera como salvoconducto para la vida eterna, sólo puede serle restituida al hombre a través del pan, de la carne, de Dios; por esa razón cantará el estribillo: "Al billano se la dan / la ventura con el pan").

Ahora bien, la única manera posible de conjugar todo lo anterior, o sea, lo inefable con lo real, lo inaprensible con lo tangible se ha de realizar, pues, en ese plano superior que es el ámbito de la obra artística donde los resortes de la imaginación y de la intuición son los verdaderamente válidos para mover la vida, para encauzar las eternas contradicciones del hombre que transitan entre la realidad efímera y la verdad absoluta; contradicciones que el artista barroco conocía a la perfección, pues era consciente de que tras la apariencia material de los seres y de las cosas - que él se encargaba de plasmar de modo tan realista y descarnado, a veces-, palpitaba un hálito espiritual, un alma propia y única dependiente, eso sí y sobre todo, de la mano de Dios. De ahí también, además, la necesidad que muestran estas piezas de combinar lo serio con lo cómico para reforzar sus conexiones con la vida natural. Así lo aconsejaba Lope de Vega en $E l$ arte nuevo..., cuando se había de escribir una de ellas:

"Lo Trágico y lo Cómico mezclado,

[...]

Harán graue vna parte, otra ridícula,

Que aquesta variedad deleyta mucho,

Buen exemplo nos da naturaleza

Que por tal variedad tiene belleza." ${ }^{41}$

La ensalada como espejo de la vida misma y como proposición estética está emparentada - lo he dicho antes - con el ambiente teatral de la época que tratamos y también, lógicamente, con ese otro espejo de costumbres que resulta ser la comedia, en la que los espectadores ven reflejadas y tratadas con arte, es decir, sublimadas e idealizadas, sus propias costumbres y de la cual aceptan, de buen grado o por rutina, su tono didáctico y moralizador que trasciende del simple divertimiento. Al final de su poema expositivo se planteaba Lope:

“[...] en medio de sus chanzas qué cuestiones serias propone o entre alegres bromas qué asuntos trascendentes va mezclando." 42

41. Lope de VEGA, op. cit., vv. 174-180, pp. 291-292.

42. Estos versos son diez en total y figuran en latín en la obra original del Fénix (vv. 377-386, p. 301, de la edición que manejo). Cito el fragmento que me interesa de la traducción que viene en la p. 239 (nota 1). 
En relación a la pieza que nos ocupa ya hemos visto cuáles eran esas cuestiones o asuntos trascendentes, y que podemos considerar como un intento de exteriorizar dramáticamente los conflictos y situaciones de la vida interior. De esta manera y con el simple giro ideológico y conceptual de remedar «a lo divino» una cancioncilla de carácter profano perfectamente conocida por todos, el autor de esta ensalada consigue revestirla de una aureola metafísica y dotarla de un significado lo suficientemente oculto para que, por fuerza, tenga que precisar del mecanismo mental de la imagen simbólica para su mejor explanación. Baltasar Gracián, en su Agudeza y arte de ingenio (1648), sostenía que para que las figuras retóricas tuvieran el valor de «agudezas», era necesario que demostraran la sutileza de un fino artificio y el carácter «picante» de «alguna circunstancia especial», es decir, la intención de retardar la intelección del «concepto» con el concurso del «ingenio». Los autores de la presente ensalada, unas décadas antes, practicaban ya este doble juego de insinuación y recato trasladado al mundo del arte, y así concebían su obra con inteligencia pero la exponían con ingenio, y con los recursos técnicos imprescindibles para que resultara algo misteriosa, un poco críptica, para contribuir de ese modo a la satisfacción final, precisamente por su resistencia a la aprehensión intelectual. No es válido únicamente, pues, el frío recurso de la razón objetiva; se necesita también el requiebro de la subjetividad que sólo el simbolismo poético y el aliento musical del arte pueden otorgar. Y los hombres de aquella época eran conscientes de ello: el poeta culto divinizador, el músico buen compositor, los intérpretes mitad cantantes mitad cómicos, el público espectador, bullicioso e inocentón, todos inmersos en la misma idiosincrasia y en la misma ideología, y todos, también, participando del mismo ideario estético y de idéntica propuesta cultural.

En vano he intentado averiguar el nombre del autor del texto poético de nuestra ensalada ${ }^{43}$, ni aun el de la música. Es posible que ambos autores (porque no era frecuente que fuera uno solo) estuvieran más atentos a conseguir la representación verdadera de lo que ansiaban espiritualmente, que no a halagar su vanidad con los honores de la fama en este mundo. En este sentido es ilustrativo el hecho de que no figure al final de la ensalada el típico broche final en latín, ese breve aforismo que la sintetiza, pero que también puede ser considerado como una concesión culta y elegante del autor deseoso de impresionar a su público, tanto por la infalibilidad —en su sentido más teológico y dogmático- que encerraba la moraleja al estar escrita en lengua latina,

43. Vid. nota 33. Sin entrar en el espinoso tema de la autoría, quiero citar los últimos versos de una "Ensaladilla vuelta al Santísimo Sacramento" del maestro VALDIVIELSO por su parecido con los versos 73-76 de la que nos ocupa, si bien aquélla trae una sentencia en latín (el inicio del conocido himno litúrgico «Te Deum»), mientras que en la nuestra viene la cancioncilla tradicional:

"Los demás, que madrugaron

y el divino pan comieron,

con gracia gracias le dieron,

y así alegres le cantaron:

Te Deum laudamus,

te Deum confitemur."

En J. M. Aguirre, José de Valdivielso y la poesía..., p. 83. 
como por el prestigio que otorgaba su conocimiento y dominio. Puede que también el carácter funcional de este tipo de obras, lo precario de su retención en la memoria de las gentes o su siempre cuestionada calidad estética entre las mentes académicas de la época fueran motivos suficientes para no preocuparse en perpetuar el nombre de sus creadores. Sea como fuere, parecía norma común que poeta y músico intentaran demostrar lo que en opinión de Wardropper venía a significar "la sinceridad humilde de los dramaturgos y el sentimiento que tenían de pertenecer a una colectividad consagrada al culto de Dios y a la difusión de los conocimientos divinos." ${ }^{44}$

\section{Problemas de transcripción musical}

¿Edición facsímil del original si sus condiciones de conservación y lectura lo permiten?; ¿o transcripción paleográfica según criterios estrictamente musicológicos y científicamente fiables para el músico teórico?; ¿o transcripción musical a partir de una metodología pragmática que facilite la interpretación a cargo del músico práctico?; ¿o quizás una solución intermedia, de compromiso, para apaciguar a ambos y en realidad no satisfacer a ninguno? Al parecer, los musicólogos de hoy estamos condenados a navegar entre Escila y Caribdis cuando abordamos la transcripción a notación moderna de la música de finales del siglo XVI y principios del XVII. Seguramente la transcripción que yo propongo no es ni la más aproximada ni la más alejada de la ideal de cuantas circulan en nuestra disciplina. Es una de tantas, ni mejor ni peor que otras muchas; es más, estoy por decir que hay tantas transcripciones como musicólogos, y quien más quien menos ostenta la suya propia con lógico y humano orgullo. En mi opinión creo que es imposible dar con la verdadera; me refiero a una que convenza a todos, máxime tratándose del tipo de música de esta ensalada, que es culta porque se ha conservado escrita en un códice entre otras piezas con nombre de autor y todo hace presumir que también ella tuviera su creador, pero popular en su origen, o al menos popularizante en su intención y difusión social. Así, el esfuerzo (¡deontológicamente hay que hacerlo!) que representa recurrir al laberinto de la teoría musical coetánea como tabla de salvación no siempre compensa; entre otras cosas, porque ni los propios tratadistas tenían claras muchas normas. No se trata tampoco de achacar sistemáticamente al copista los reales o hipotéticos errores observados; es una postura demasiado cómoda, sólo plausible en casos evidentes. Sin embargo, lo que tampoco podemos hacer es mirar el manuscrito como un fetiche o una reliquia inviolable donde todo haya de ser verdad; y menos el que nos ocupa cuya caligrafía no es precisamente un dechado de perfección ni de belleza, pues en él se alternan, a veces, las tachaduras con los párrafos de música y de texto que se empequeñecen de repente por no disponer de espacio suficiente. Nuestro copista era pulcro sólo a medias y, como todo ser humano, se equivocaba; y al equivocarse omitía, añadía, sustituía, rectificaba y alteraba, $y$ todo esto se ha tener presente a la hora de transcribir la pieza ${ }^{45}$.

44. Bruce W. WARDROPPER, Introducción al teatro religioso del Siglo de Oro..., p. 205.

45. A los musicólogos, que compartimos con los filólogos el estudio de obras como la presente, nos viene bien el excelente libro de Alberto Blecua, Manual de crítica textual, Madrid, Ed. Castalia, 1983, sobre todo las pp. 15-30. 
Por otra parte, en este tipo de música es importante no confundir metodología o sistema científico con aprehensión de la realidad simple y llana que, por supuesto, no se contempla en ningún tratado teórico. El tributo puede pagarse en forma de pirueta intelectual de cuyo influjo será difícil sustraerse después. En consecuencia, es más eficaz, creo, acometer la transcripción dejando que prevalezca la intuición musical, porque posiblemente éste era el recurso más importante que animaba al compositor de esta clase de música, probablemente también el que orientaba al copista y seguramente el que prevalecía en la actitud del intérprete. En este caso, pues, la partitura sería un mero procedimiento mnemotécnico, un simple código orientativo, incluso, prescindible si tenemos en cuenta la opinión de Salinas, para quien "la composición musical que suele ejecutarse en las asambleas profanas y en los banquetes de los príncipes no es tan complicada de voces que no pueda cantarse sin partitura" ${ }^{46}$. Sobre todo, si son sólo tres y en homofonía la mayor parte de la pieza, se podría añadir. Además, paralelamente, en los géneros teatrales menores, donde quizás esta ensalada se podría interpretar, las reglas sobre la teoría dramática (unidad de acción, de lugar y de tiempo) no se observaban con el mismo rigor que exigía la preceptiva clásica para otras obras de mayor empaque.

Permítaseme establecer una comparación, quizá oportunista, recurriendo otra vez al Arte nuevo... de Lope. Cuando el Fénix emprendía la escritura de una comedia pensaba ante todo en complacer al público al cual iba destinada; un público que se apretujaba en los corrales y que, pagando con su dinero, exigía un lenguaje comprensible exento de conceptos oscuros, un argumento extraído de la vida cotidiana con los tópicos convencionales de la época y una planificación de la obra al alcance de su mentalidad, es decir, alejada de la rigidez de los preceptistas que defendían la Poética aristotélica. Por eso Lope manifestaba:

\footnotetext{
"Y, quando he de escriuir vna Comedia, Encierro los preceptos co[n] seis llaues; Saco a Tere[n]cio y Plauto de mi estudio, Para que no me den vozes, que suele Dar gritos la verdad en libros mudos. $\mathrm{Y}$ escriuo por el arte que inuentaron Los que el vulgar aplauso prete[n]diero[n], Por[que], como las paga el vulgo, es justo Hablarle en necio para darle gusto."
}

En nuestro caso, el destinatario de esta ensalada era el mismo público que asistía a las representaciones teatrales en los corrales, a las funciones de títeres, a las romerías y fiestas campesinas, y el que se complacía en escuchar la interpretación de letras, letrillas, villanescas y villancicos - en ensaladas y ensaladillas - en las paradas de las procesiones del Santísimo Sacramento, o en las fiestas solemnes del año como la Navidad, los días de Nuestra Señora o de santos particulares, etc.; interpretación polifónica, se entiende, que tanto le deleitaba y cuyo artificio no lograba comprender. "Respecto al arte de cuatro o más voces — se lamentaba

46. Francisco Salinas, Siete libros..., p. 500.

47. Lope de VEGA, op. cit., vv. 40-48, pp. 284-285. 
Salinas- ¡qué pequeño es el número de personas que, aun entre los doctos, tan sólo medianamente llega a entenderlo! No obstante, todo el mundo al oírlo lo alaba para no ser tenido por inculto" ". En consecuencia, ¿sería descabellado pensar que el músico que compuso esta música, o el amanuense que la copió, o aún los intérpretes que la cantaron encerraran también bajo llave algunas normas relativas a la composición, al enrevesado sistema de notación musical o a la ambigüedad de la semitonía subintelecta, respectivamente?; ¿o que, incluso, llegaran a sacar a Cerone o a cualquier otro tratadista de su estudio, aunque sólo fuera por un momento, para que no gritaran ante un ennegrecimiento de menos o una alteración de más? A fin de cuentas este tipo de música en concreto la había de gustar el pueblo llano y las sutilezas expresivas de la teoría, de la notación o de la retórica aplicada al discurso musical se acomodarían mucho mejor a composiciones más solemnes, de mayor enjundia, que merecieran los honores de la imprenta, su audición en ceremonias importantes, en el templo o en la corte, y el aval de un compositor de prestigio que no dudara en poner su nombre al frente de la obra.

La dualidad de situaciones y formulaciones que subyace en el contenido ideológico de esta ensalada y que ya hemos visto sobradamente (sacro / profano; culto / popular; seriedad / comicidad), creo que muy bien puede trasmutarse a la hora de abordar su transcripción. Así, una cosa será la elucubración y la especulación teórica y otra muy diferente la práctica musical. Además, y volviendo a Salinas, es significativo, también, su testimonio cuando afirma que "es raro encontrar cuatro o cinco personas que sepan cantar suave y sabiamente, ya que casi siempre se comete algún error que molesta y fatiga no poco a los oyentes" ${ }^{49}$. Si ellos, que conocían su propio lenguaje musical con su técnica específica, con sus recursos y sus carencias, y sabían perfectamente cual era la manera ideal de adaptarlo a la interpretación de sus obras; si atendían con propiedad a la gesticulación correspondiente, a la caracterización de los personajes, al dinamismo de las situaciones escénicas y a la dramatización del texto y de la música, porque hacían derivar todo esto de su concepción de la vida, claro está; si de tal manera teatralizaban la obra en el modo de articular, de atacar y frasear el discurso musical según el sentido de las metáforas del texto, de los convencionalismos mentales de la época que ellos entendían a la perfección, de las sutilezas del humor y de la parodia, de los requiebros del lenguaje y su doble sentido, de la intención de transcedencia y espiritualidad en su sentida religiosidad, de la actitud de sus ansias vitales con sus momentos de euforia y de desengaño. En fin, si ellos, a pesar de todo, cometían algún error contra los postulados de los tratadistas era debido a que se dejaban llevar más por la intuición de una práctica artística de consumo inmediato y sin apenas reflexión intelectualizada, que no por la fría observancia de las reglas. En consecuencia era lógico, pues, que incurrieran en algún error contra la teoría. Pero sólo contra la teoría, nunca contra el arte; entre otrăs cosas porque su arte era sincero.

Ahora nos toca a nosotros, estudiosos y artistas que vamos a encarar un nuevo milenio, reinterpretar, si queremos, esta ensalada y apropiarnos de los conocimientos que su lectura y

48. Francisco Salinas, Siete libros..., p. 500.

49. Ibidem. 
entorno nos puedan deparar. Seguramente cometeremos en este intento más errores que las personas de las que se quejaba el ciego Salinas, que, a fin de cuentas, sólo se equivocaban en la técnica artística, y no corrían el riesgo de desvirtuar la intencionalidad de la obra; error éste infinitamente más grave y que nos acecha constantemente en nuestros planteamientos de recuperación de obras literariomusicales antiguas. Pero quizás podamos aprender la lección de lo que significó el arte barroco, o mejor dicho, de lo que supuso para la cultura occidental del siglo XVII la manera barroca de entender la vida; porque el barroquismo es algo más que una pose estética - tan vulnerable a la crítica racional-, o una estructura histórica - tan estática y aséptica por su falta de compromiso espiritual-, es asimismo una ideología, una postura vital, cuyas características y rasgos más sobresalientes aún hoy cobran actualidad y mantienen su vigencia, pues los apreciamos en nuestros días, donde la angustia del hombre de ahora es exactamente la misma angustia, si no más, que sentía el hombre de aquella época. Angustia ante el paso incontenible del tiempo, inquietud ante el incierto futuro, temor para afrontar la escalofriante eternidad. Son los sentimientos que experimentamos también cuando actualizamos y revivimos aquel tiempo pasado a través de las obras que se nos han conservado, y nos identificamos con su sensibilidad; sentimientos que, en definitiva, constituyen el ineludible tributo que hemos de pagar por la búsqueda de nuestra propia conciencia histórica ${ }^{50}$.

\section{Criterios de transcripción musical}

Lo que voy a intentar ahora es justificar mi transcripción, teoría en mano, pero sin llegar al extremo - espero- de que ésta me aturda a mí y ofusque al lector. He preferido no reducir los valores de las notas conservando, siempre que ha sido posible, la grafía original, con excepción de las notas ennegrecidas que se han vaciado en la transcripción y que van entre los signos $\Gamma 7$. Conviene mencionar que la mínima ennegrecida y la semimínima se escriben siempre igual en el manuscrito, aunque por el contexto en seguida se adivina cual es una y cual es otra.

Los códigos gráficos de plasmación de la música que se hacían servir en aquella época eran diferentes a los nuestros, porque obedecían a una sensibilidad distinta también de la nuestra. En consecuencia, aplicar la notación musical que hemos aprendido en el conservatorio con sus barras de compás, la medición de sus valores y la rigidez de su acentuación no nos va a servir de nada. Estamos ante poesía musicada y la prosodia musical desempeña un papel determinante, ya que conviene tener muy presente que los textos de esta ensalada siempre cantan bien, aunque nosotros, en ocasiones, no veamos clara la correspondencia entre sílabas fuertes y tiempos de compás fuertes, o sílabas débiles y tiempos débiles.

En la época que nos ocupa, la música sobre textos en lengua vernácula está regida mayoritariamente por los compases binarios $\mathbf{C}$ o $\boldsymbol{\&}$ y ternarios $\mathbf{C} 3$ o $\boldsymbol{\&} \mathbf{3}$, tanto indistinta como simultáneamente; y son muchas las piezas, como nuestra ensalada, que ofrecen una alternancia

50. Cfr. Emilio Orozco Díaz, Manierismo y barroco, pp. 59-61. 
entre ellos, es decir, que en una misma composición se dan fragmentos en compás binario, por lo general más reposados y lentos, combinados con otros en compás ternario que resultan algo más animados y ligeros. En la presente ensalada, lo que mueve a nuestro anónimo compositor a elegir entre uno u otro compás, o la combinación de ambos, es tanto el interés en explotar los contrastes dinámicos del discurso musical —ya de por sí suficientemente expresivos-, cuanto la intención en ajustarse musicalmente al sentido del texto literario con la mayor fidelidad posible. Ajuste musical que se ve condicionado por dos aspectos del propio texto: uno interno que hace referencia a su contenido poético, con el consiguiente alcance semántico, carácter alegórico y simbólico, conceptismo sacro y sus convencionalismos ideológicos; y otro externo en estrecha relación al género o forma literaria empleada (redondilla, letrilla, dístico monorrimo, etc.) y que atiende al talante culto de las estrofas glosadoras y al popular del villancico o cancioncilla tradicional, a su carácter danzable, a la versificación, a los diálogos y al papel funcional del narrador. Me estoy refiriendo, claro está, sólo a aspectos rítmicos; otra cosa serán los melódicos, los contrapuntísticos y, si se me permite, los armónicos con sus relaciones modales y tonales. En cualquier caso, todos estos aspectos necesitarían un estudio puntual y detallado que ahora no tiene cabida aquí.

Por otra parte, si observamos detenidamente los fragmentos binarios veremos que, en efecto, corresponden en líneas generales a asuntos graves y serios (vv. 5-6 y 13-14 [cc. 11-16]), e incluso son cantados con cierta solemnidad, como la intervención del vizcaíno (vv. 41-52 [cc. 58-81]) y el estribillo tradicional glosado en la gran síntesis final con acción de gracias incluida. Por el contrario, el compás ternario es utilizado en pasajes más alegres y divertidos, como son las actuaciones del sacristán y de la gitana, y en el remate de algunos estribillos (vv. 7-8 y 15-16 [cc. 17-26]).

En principio, el compás binario \& no presenta problemas y lo transcribo con el 2/1, siendo una breve ${ }^{51}$ su unidad de valor. En relación a la diferencia entre ambos compases, sin partir y partido, dice Cerone que

“[...] el tiempo más usado de todos quantos ay es el del compassete; y la señal que nos da a entender que cantemos a compasete, o como dizen otros a compasillo, es el medio círculo en esta forma C. En este tiempo, pues, sin línea atravessada [...] la breve [vale] dos [compases y] la semibreve un compás [...].

»[...] el mesmo medio círculo, siendo con una línea o raya atravessada, causa otro differente effecto, en quanto al dar el valor a las figuras; y es llamado tiempo de por medio, compás de la breve, o compás entero. La señal deste tiempo digo que es medio círculo cortado y atravessado con una raya, ansí $\phi$. La qual nos advierrte que la [...] breve [vale] un compás, y que dos semibreves $[\ldots]$ van por un compás $\left[\ldots . . .,{ }^{, 52}\right.$

Sin embargo, hay que tener en cuenta que en el primer cambio de compás de la pieza la voz inferior trae $\mathbf{C}$, seguramente por error del copista, puesto que en todos los restantes cambios

51. Equivalente a nuestra cuadrada; el programa informático de notación musical empleado la sustituye por una redonda con barritas a los lados (\|اO\|).

52. Pedro Cerone, El melopeo y maestro. Tractado de música theórica y prática, Bologna, Forni Editore, 1969 [edición anastática en dos volúmenes de la de Gargano y Nucci, Nápoles, 1613] , vol. I, p. 498. 
de compás y en todas las voces figura siempre el signo de compás \$. De estos descuidos o incongruencias se queja Cerone:

"Muchos se hallan que con poca consideración hazen el compás a beneplácito, estando la señal indicial de una composición assí ф señalada con diminución virgular, la qual medida no será la propria que a la dicha señal conviene, pues dan el compás sobre de una semibreve, haviendo de ser una breve $[\ldots] ., 53$

Es decir, que ya había compositores o intérpretes en la época poco atentos en observar la diferencia entre el compás sin partir y el partido, llevados seguramente más por una práctica secular o rutinaria que por ignorancia.

El compás C 3 es algo más controvertido. Ante todo veamos la descripción que hace Cerone del compás ternario en general:

"La segunda manera de compás es ternaria o desigual que llaman vulgarmente compás de proporción ternaria; y es porque mide tres figuras o su equivalente a cada compás: como si es mayor, tres semibreves; y si es menor, tres mínimas. Y esta proporción ternaria puede ser tripla, midiendo tres figuras contra una; o sexquiáltera, midiendo tres contra dos [...].,54

Y es más controvertido porque en su grafía presenta algunas discrepancias. En la época eran muy usuales los siguientes signos para designar el compás ternario:

C 3/2 para la proporción mayor; C3 para el ternario. En ambos la breve perfecta vale un compás y la semibreve una parte de compás.

C 3, CZ y \&Z para la proporción menor. En los tres la semibreve perfecta vale un compás y la mínima una parte de compás ${ }^{55}$.

Parece evidente que en nuestra ensalada el signo utilizado para el compás ternario es el C3, que manuscrito es el CZ y cuyo funcionamiento, según la teoría, resultaría idéntico aunque apareciera partido. En consecuencia, deberíamos transcribir los fragmentos ternarios atendiendo a los valores asignados a la proporción menor, es decir, una semibreve perfecta al compás y una mínima a cada parte. Sin embargo, considero que puede sernos lícito pensar que si el copista se equivocó en el compás binario - y esto indefectiblemente es así-, de la misma manera pudo equivocarse también en el ternario y confundir la proporción menor con la mayor, puesto que los signos son muy similares. En casos como éste conviene observar la figuración de las notas, que en bastantes ocasiones resulta suficientemente clara. Así lo aconseja Lorente cuyo testimonio no deja lugar a dudas al respecto:

"Adviértase que aunque no aya puesto tiempo en las cantorías, las figuras hazen tiempo, dándole tácitamente a entender; esta advertencia es bien la observen todos, porque se ve muchas vezes, o por descuido del que subscribe la obra, o por advertencia o inadvertencia del que la hizo, no poner tiempo en ella; y si no se atiende a las figuras que tiene en su discurso, o se quedará sin cantar, o no se les dará el valor que les pertenece y pide a cada una de las notas o figuras." 56

53. Ibidem, vol. II, p. 754.

54. Ibidem, p. 750 .

55. Así lo detalla gráficamente Andrés LoRENTE en su tratado El porqué de la música, Alcalá de Henares, 1672 , p. 186.

56. Ibidem, p. 181. 
Observada, pues, la figuración de las notas todo parece indicar que nos hallamos ante una proporción menor - y efectivamente así es-, con lo cual una transcripción en 3/2 sería fluida y natural, siempre y cuando no surgieran notas ennegrecidas o hemiolias. Pero como éstas en seguida van apareciendo - concretamente a partir del tercer compás en pequeños núcleos y conforme avanza la pieza en largas sucesiones (dejemos de lado el ennegrecimiento del primer compás)—, nos damos cuenta entonces de que el compás 3/2 no nos permite cantar los textos con comodidad, ni podemos extraer tampoco todo el juego expresivo que nos brindan las notas ennegrecidas con su acentuación intensiva tan característica y su sincopado contraste con las demás. Ni mucho menos nos da opción a ofrecer una transcripción correcta a nivel paleográfico, porque para aproximarnos, hermenéuticamente hablando, a la intencionalidad de escritura de esta ensalada en concreto, deberíamos sembrar los pentagramas de continuas fracciones con que expresar los cambios de compás o utilizar en exceso los compases de amalgama; o lo que creo que es peor: fraccionar el valor de una nota de larga duración y subdividirla en otras que forzosamente habrán de estar ligadas entre sí, con el consiguiente mal efecto que produce a la vista una tal profusión de ligaduras y síncopas irregulares escritas artificialmente.

Para la transcripción moderna se impone, en mi opinión, una solución intermedia que sea respetuosa con la teoría y congruente con la práctica. Para ello, a nivel teórico, es necesario recurrir a la proporción mayor, es decir, una breve perfecta ${ }^{57}$ al compás y una semibreve ${ }^{58}$ en cada parte, o valores equivalentes, cuando el discurso musical así lo requiera. Y a nivel práctico, conviene distribuir los valores dentro de los compases de la manera más musical posible para que los textos canten bien. En consecuencia, el compás elegido será una alternancia entre 6/2 y 3/1 que creo será el más oportuno para respetar las hemiolias y la acentuación del texto. De esta manera, el 6/2 funcionará como un compás binario de subdivisión ternaria y el 3/1 como uno ternario, y en ambos casos se sabrá fácilmente cuando se trata de uno o de otro por la disposición de las notas en la transcripción. No habrá dificultades de ejecución en los fragmentos homofónicos; en cambio, en los pasajes escritos en contrapunto imitativo, se habrá de poner especial cuidado, pues cada voz en particular evolucionará según el texto que cante en ese momento y no siempre concordará con sus vecinas (cc. 22-23 y 88-90, por ejemplo).

En todo caso, en mi transcripción habré pretendido emular una de las características más sobresalientes que se adivinan en este tipo de música, es decir, aquello que es válido para la teoría quizá no lo sea tanto para la práctica. Llevando el discurso a donde me interesa, leo en Lorente:

“En proporción mayor hazen el breve perfecto por uso, no por razón En proporción menor hazen el semibreve perfecto por uso, no según arte." 59

Se puede deducir, pues, que en la práctica se había recurrido a la perfección de la breve y de la semibreve al margen de los conceptos tradicionales de tiempo y prolación, y esto se hacía

57. Equivalente a nuestra cuadrada con puntillo; cuando sea imperfecta vendrá sin puntillo.

58. Equivalente a nuestra redonda que irá con o sin puntillo dependiendo de si es perfecta o imperfecta. Las otras figuras se transcriben así: la mínima y la mínima ennegrecida equivalen a nuestra blanca y la semimínima a nuestra negra.

59. LORENTE, op. cit., p. 186, concretamente en una columna que figura al lado derecho de la tabla. 
muy posiblemente en beneficio de una nueva manera de atacar el discurso musical y de cuidar las relaciones entre texto y música, como acabamos de ver. Esta dialéctica entre la teoría (entendida como razón o arte) y el uso -fácilmente extrapolable a, y desde, las diversas dualidades que subyacen en el argumento de esta ensalada: apariencia/realidad, espíritu/materia, etc., ya analizadas anteriormente-, es señalada también por Cerone, dicho sea de paso, uno de los teóricos más denostados por la historiografía musicológica posterior:

"Más todavía (considerado que el uso es otra ley) [...] sintamos con los pocos [teóricos] y usemos con los muchos [prácticos], aunque es contra razón. [...] Que quien hiziesse agora en contrario, parece ya que haría error. Pues sabemos que a vezes el uso tiene mayor fuerça que la ley; y es otra ley." 60

Un hecho significativo en este tipo de música se da en el concepto de proporción. Pero, ante todo, tengamos claro que el compás no varía nunca y el mismo valor tiene uno ternario que uno binario. Así, se establece una primera proporción con el cambio real de compás ternario a binario - por seguir el orden que propone la pieza—, que nos indica esta serie de relaciones:

\section{Compás ternario C3}

1 breve con puntillo (perfecta)

2 semibreves con puntillo (perfectas)

6 mínimas
Còmpás binario $€$

$=1$ breve sin puntillo

$=2$ semibreves sin puntillo

$=4$ mínimas

Dicha relación, digamos de tipo cuantitativo, afecta únicamente al valor de las mínimas, las cuales pierden un tercio de su valor en el ternario - o lo ganan en el binario-, resultando su ejecución más rápida —o más lenta-. Y prescindo conscientemente de los puntillos de la breve y de las semibreves porque no importa en absoluto que lo lleven o no, en este caso concreto, ya que su ejecución es idéntica en ambos compases. Debo reconocer que estoy teorizando sobre un hipotético compás ternario en el que las notas mayores fueran siempre perfectas, puesto que

“[...] en los números ternarios - dice Cerone- no se han de escurescer las figuras, si no es por fuerça de imperfección [...].",

Para imperfeccionarlas, pues, y poder escribir breves y semibreves sin puntillo en compás ternario, había que recurrir a un artificio simple y práctico: la hemiolia, consistente en llenar las notas de color o ennegrecerlas. Es entonces cuando en ese teórico compás ternario se da otro tipo de proporción, cuyas relaciones - aunque continúan siendo de carácter cuantitativo para las breves y la semibreves que pierden la tercera parte de su valor-, son ahora de tipo cualitativo para las semibreves y las mínimas que cambian su acentuación. En relación a la pérdida de valor de las notas, y entre otras cosas que también son interesantes, dice Cerone :

"[...] cada figura compuesta de número ternario, siendo llena de color, queda imperfeta; es, a saver, queda diminuyda de la cantidad de una tercia parte. Para cuya intelligencia advierto que

60. Cerone, op. cit., vol. II, p. 1004.

61. Ibidem, vol. I, p. 522. 
no se puede poner una sola figura llena, mas conviene le sigua [sic.] otra figura negra que cumpla el número ternario (o más números ternarios) y es que la cantidad que pierde una figura mayor por la color, se ha de dar a otra menor."62

Si tenemos en cuenta que para recuperar la perfección en las notas ennegrecidas se ha de recurrir de nuevo al uso de los puntillos, tendremos las siguientes relaciones:

\section{Compás ternario}

1 breve con puntillo (perfecta)

2 semibreves con puntillo (perfectas)

6 mínimas

\section{Hemiolia}

$=1$ breve con puntillo

$=3$ semibreves sin puntillo

$=6$ mínimas

Los teóricos de la época llamaban proporción sexquiáltera a la hemiolia. Veamos en primer lugar el testimonio de Cerone:

"Ay después a vezes que todas las figuras son negras y llenas, y entonces (como queda dicho) es canto que llaman hemiolia, proporción sexquiáltera; y assí es del número ternario en el compás, en cuyas figuras no hay perfección, alteración ni división." ${ }^{63}$

Conviene señalar, además, que esta proporción solía expresarse también con la fracción 3/2; su razonamiento genérico lo hacía Cerone de esta manera:

“[...] la sexquiáltera [...] se causa quando el número mayor contiene al menor una vez y más la mitad; como de 3 a 2.

»[...] Aplicada al compás, es quando tres puntos semejantes son pronunciados contra dos en un compás, o seys contra quatro, etc. Cantando, pues, en una voz tres semibreves, breves o mínimas, etc., y en otra dos, llamarse ha sexquiáltera proporción. Señálase con un tres y baxo dél un dos; assí $3[/] 2 . " 64$

Y para Lorente resultaba indiferente la manera de escribirla, puesto que la daba por sobrentendida por la figuración de las notas:

“[...] las figuras de nota negra son de proporción sexquiáltera y que en qualquiera tiempo que se hallaren, sin que le pongan particular, son siempre del número ternario; en las quales figuras no ay perfección, alteración ni división; sólo puede aver en ellas puntillo de augmentación $[\ldots]$,

No quiero alargarme más en disquisiciones teóricas que muchas veces se van al traste cuando las enfrentamos a la realidad musical. Voy a poner ahora un ejemplo práctico con el que espero paliar en parte la insatisfacción que me produce siempre hurgar en la teoría. Insisto en que sea cual sea la combinación de figuràs, lo importante es distinguir claramente cuando el compás

62. Ibidem.

63. Ibidem, p. 521. Y reitera más adelante: “[...] assímesmo se acostumbra de apuntar la sexquiáltera y es sin números: escrívese llena de color, llamada comúnmente hemiolia." (Vol. II, p. 1005).

64. Ibidem, p. 986.

65. LORENTE, op. cit., p. 181. 
es binario o cuando es ternario. Si observamos los tres primeros compases de la voz del Canto, veremos que los dos primeros son binarios y están escritos en $\mathbf{6} / \mathbf{2}$, mientras que el tercero es ternario y está escrito en 3/1. Lógicamente, los compases, aun aiendo todos idénticos en valor, traen sus figuras distribuidas de manera diferente. Lo que los diferencia en realidad - además de la impresión que tenemos a primera vista de que los dos primeros son binarios y el tercero ternario-, es la constatación práctica del peculiar ataque y articulación interna de cada uno de ellos en su relación con el texto.

Veamos a continuación un caso híbrido, es decir, aquellos compases en los que la figuración de las notas no nos aclara si son binarios o ternarios: tal es el caso del segundo compás del Alto, o el cuarto del Canto. Cualquier cantante los interpretaría binarios porque resulta muy musical, y muy expresivo, acentuar el tercer Sol del Alto (en disonancia con el LA del Canto), o el cuarto Re del Canto (en disonancia con el Mi del Alto), que actúan como auténticas apoyaturas -en realidad son retardos desligados con carácter de apoyaturas-, y que piden, tras su percusión disonante y su descenso melódico al encuentro de sus respectivas notas «sensibilizadas» (FA\# y Do $\sharp)$, su correspondiente resolución consonante. Sin duda sería una interpretación correcta y artísticamente coherente, puesto que la acentuación de casi todos los textos así lo exige, pero si observamos la $2^{\text {a }}$ línea del texto del Alto (compás 2), que dice:

$$
\text { I el por - tu- I gués; }
$$

o la $4^{\mathrm{a}}$ línea del Canto (compás 4), que reza así:

$$
\text { I gi - ta - na lle - I gó. }
$$

¿Qué pasaría entonces si nos empeñáramos en cantarlas con ritmo binario? Creo que sería más acertada una lectura ternaria de esos fragmentos en concreto, para evitar acentuar las sílabas que he señalado en negrita. Lo cual demuestra que la música, al escribirse una sola vez para toda la pieza, no siempre se acomodaría a los diferentes textos con la misma naturalidad, y habría que ir adaptándola a cada uno de ellos en particular.

Entramos ahora en el asunto tan controvertido de las divisorias. En realidad, si espaciáramos convenientemente los textos y los grupos de notas y dispusiéramos con pulcritud la correspondencia entre sílabas y notas, no harían falta alguna las líneas divisorias, sobre todo, en pasajes homofónicos; otra cosa son los fragmentos en contrapunto imitativo que siempre resultan de lectura algo más complicada. Las he incluido exclusivamente en los pentagramas para facilitar el manejo de la pieza cuando se citan compases numerados. Notará el lector que algunas divisorias son discontinuas, como líneas de puntitos. Ello obedece a que los compases que empiezan o terminan con esa divisoria especial son en realidad medios compases (aunque se numeren igual que los completos y funcionan tanto en $\mathbf{C} 3$ como en $\$$ ). De esta manera se evita el uso de los compases de amalgama y no es necesario fraccionar el valor de algunas notas con sus correspondientes ligaduras. Las divisorias o dobles divisorias que abarcan además los espacios entre pentagramas, son líneas que figuran así en los pentagramas del manuscrito y he querido respetarlas escrupulosamente. 
La pieza está escrita en claves altas por lo que sería necesaria su transposición. Sin embargo, me ha parecido más oportuno no transportarla por no condicionar a los intérpretes, ya que ellos tienen la última palabra para hacerlo al intervalo que más les convenga: una tercera, una cuarta descendente.

\section{Enmiendas a la transcripción musical}

He regularizado los calderones, tanto en las notas que no los llevaban como en aquéllas en que sobraban.

En relación a las hemiolias, he considerado importante respetarlas al máximo a pesar de su falta de rigor en ocasiones, porque son, sin duda, el punto más conflictivo de la transcripción. Así, el intérprete tendrá a mano una versión lo más ajustada posible a la realidad del manuscrito y podrá introducir los cambios que considere oportunos.

Los signos de repetición que figuran en la transcripción vienen así en el original, con alguna que otra omisión o incorrección sin mayor importancia. A pesar de su prolijidad he preferido conservarlos todos, excepto los que se observan en algunas voces y que afectan al primer verso de los tres primeros estribillos de la pieza (vid. los compases 11-12, 33-34 y 58-60). Los he omitido por la incongruencia que representa que estén en unas voces sí y en otras no, y no siempre en todos los estribillos. Es posible que su repetición viniera impuesta por razones de acompañamiento instrumental, o por recabar con mayor énfasis la atención del oyente. Como tantas veces, el intérprete tendrá la última palabra al respecto.

La cuestión de la semitonía subintelecta no presenta, apenas, problemas, al menos a primera vista. Parecen estar claros los accidentes que faltan y los que sobran. Las alteraciones añadidas se ponen encima de la nota a que se refieren y tienen validez para una sola voz y en un mismo compás. Las que van entre paréntesis denotan una interpretación ad libitum.

Otro tipo de enmiendas (teniendo en cuenta que lo que se especifica en cada compás es lo que consta en el manuscrito) son las siguientes:

\section{Canto}

c. 16: el primer Sol es una semibreve con puntillo, lo cual ocasiona una disonacia anormal con el FA del Alto. Es preferible sustituir dicho Sol por otro que sea una mínima y añadir un LA semibreve; cfr. con los cc. 31 y 99.

c. 77: sostenido sobre el Mr, igual a becuadro que se omite en la transcripción.

c. 93: el tercer Do es una mínima con puntillo con la plica tachada por dos rayitas.

c. 98: el Do es una semibreve ennegrecida con puntillo.

c. 119: el La es una breve.

$\underline{\text { Alto }}$

c. 26: el LA con calderón es una semibreve. 
c. 50: pausa de mínima y Si semibreve ennegrecida con puntillo, que se omiten en la transcripción atendiendo al contexto de las otras voces; el SoL es correcto.

c. 54: el FA es una mínima ennegrecida.

c. 62: el segundo Sol es una semibreve.

c. 71: el cuarto Sol es una semibreve.

c. 98: el LA es una semibreve ennegrecida con puntillo.

c. 100: el FA es una longa.

Las seis últimas notas del c. 117 y todas las de los cc. 118 y 119 ofrecen la siguiente sucesión: LA, LA, Si, LA, Sol, Sol, LA, LA, LA, Si, LA, Sol, Sol, LA, dando lugar a octavas paralelas con la voz superior. Propongo la sucesión total: Si, LA, Sol, FA, Mi, Mi, FA, Si, LA, Sol, FA, MI, MI, FA, que forma terceras paralelas con el canto, como sucede en otras partes de este estribillo.

\section{Tenor}

c. 50: el segundo Si es una semibreve ennegrecida con puntillo.

c. 53: pausa de mínima al inicio del compás que se omite en la transcripción.

c. 68: sostenido sobre el RE, que se omite en la transcripción.

c. 78: LA semibreve sin puntillo.

c. 81: FA semibreve sin puntillo.

c. 100: el FA es una mínima.

\section{Todas las voces}

Téngase presente que la pausa de mínima al principio de los cc. 82 y 101 no figura en el manuscrito. 


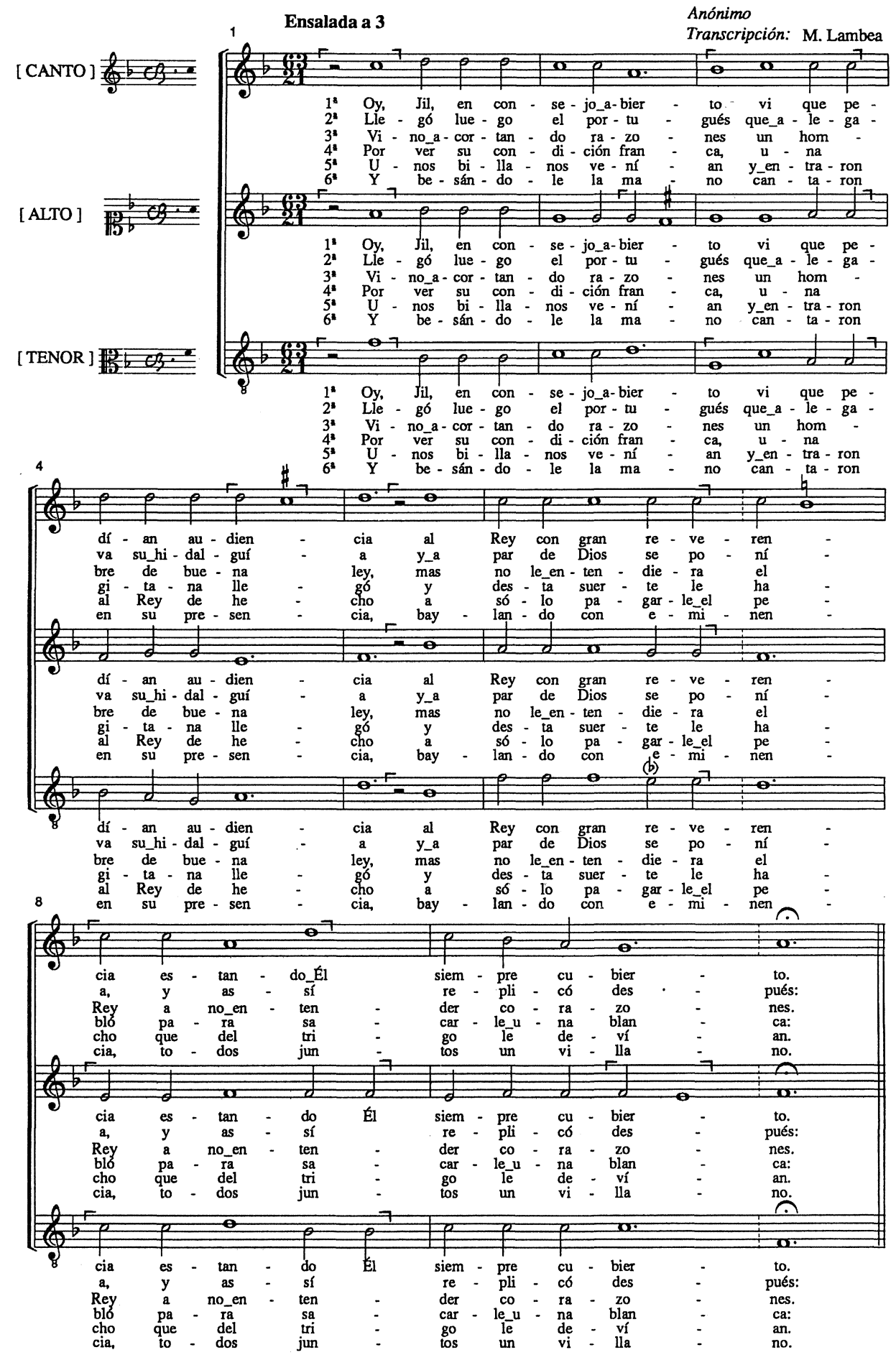



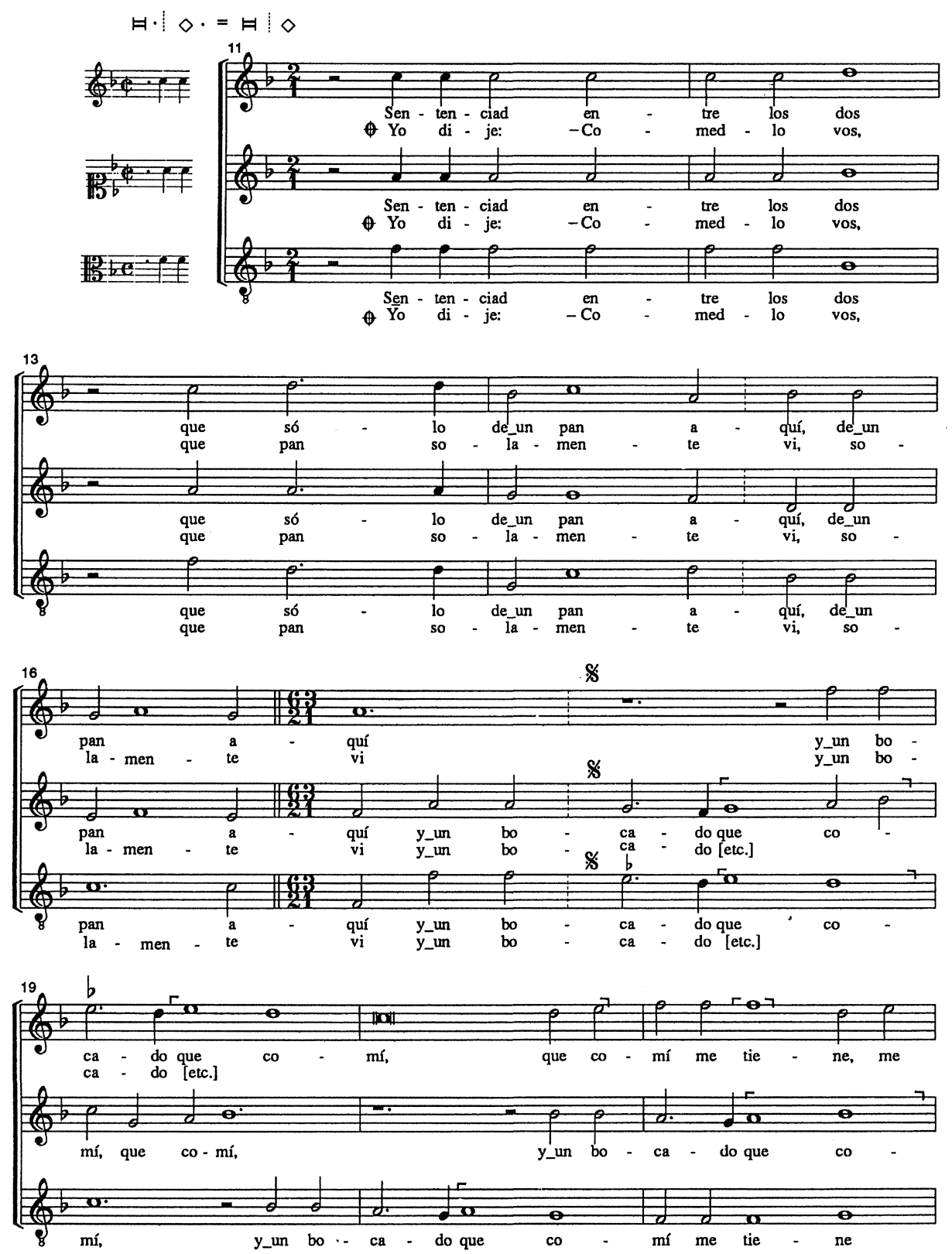

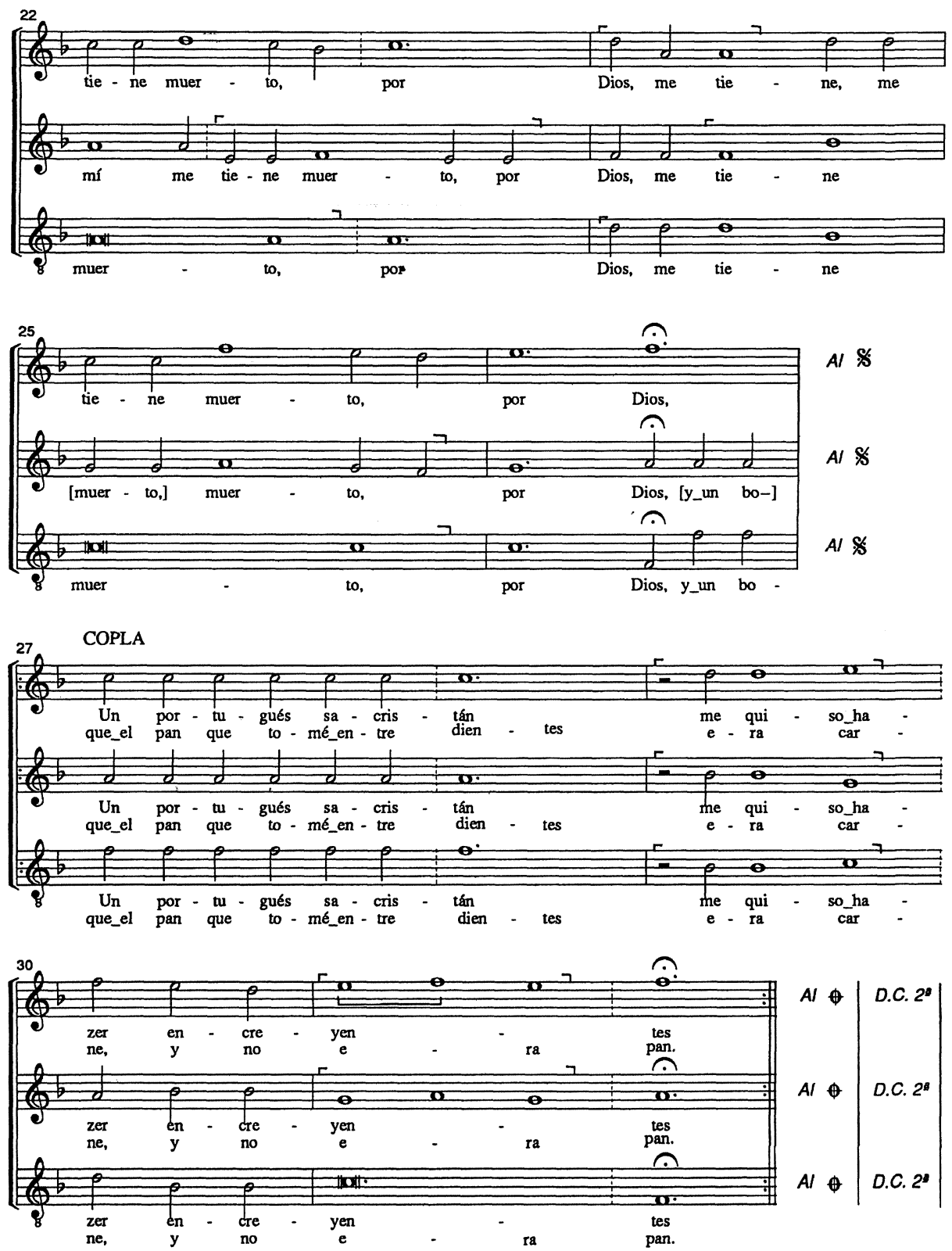

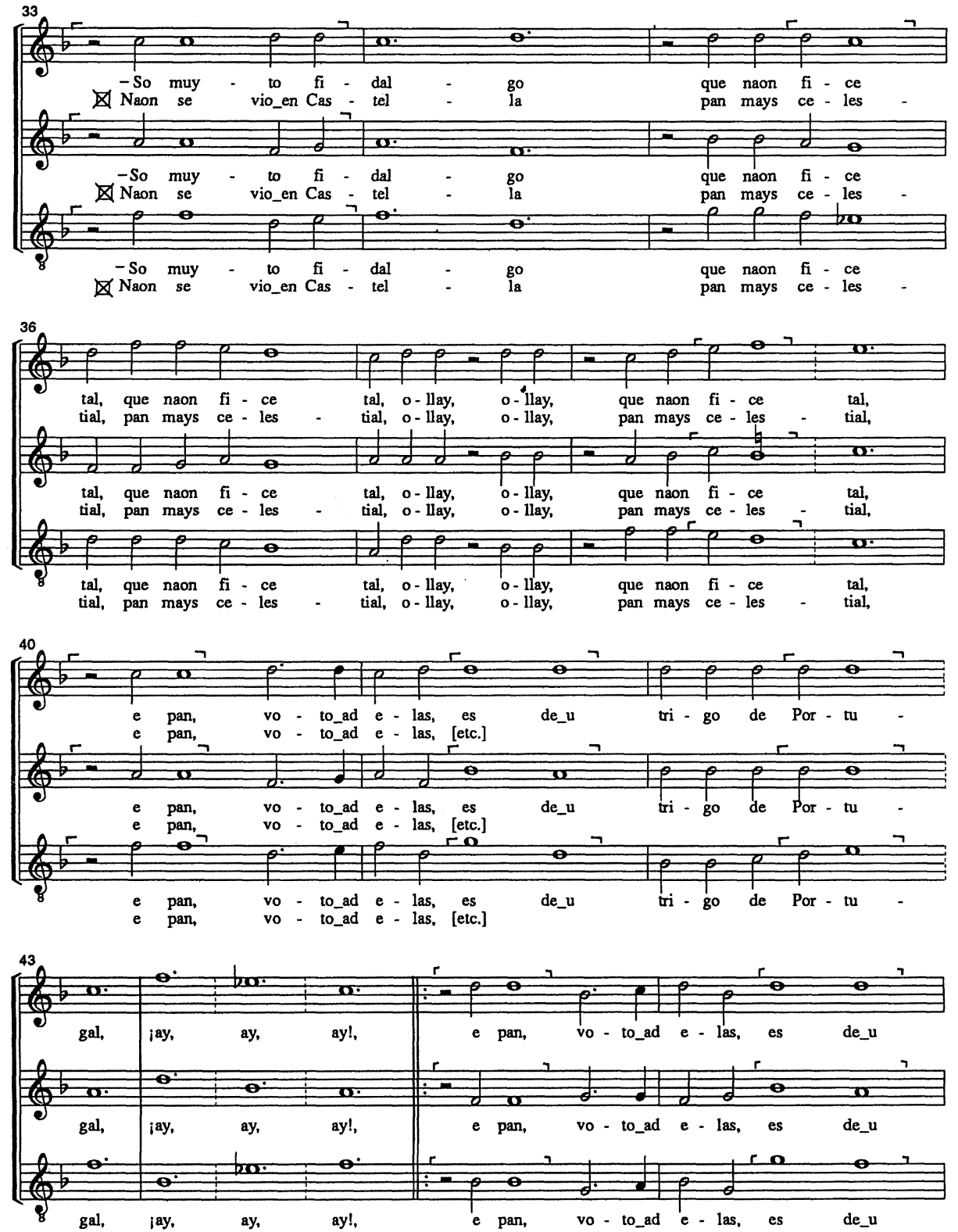

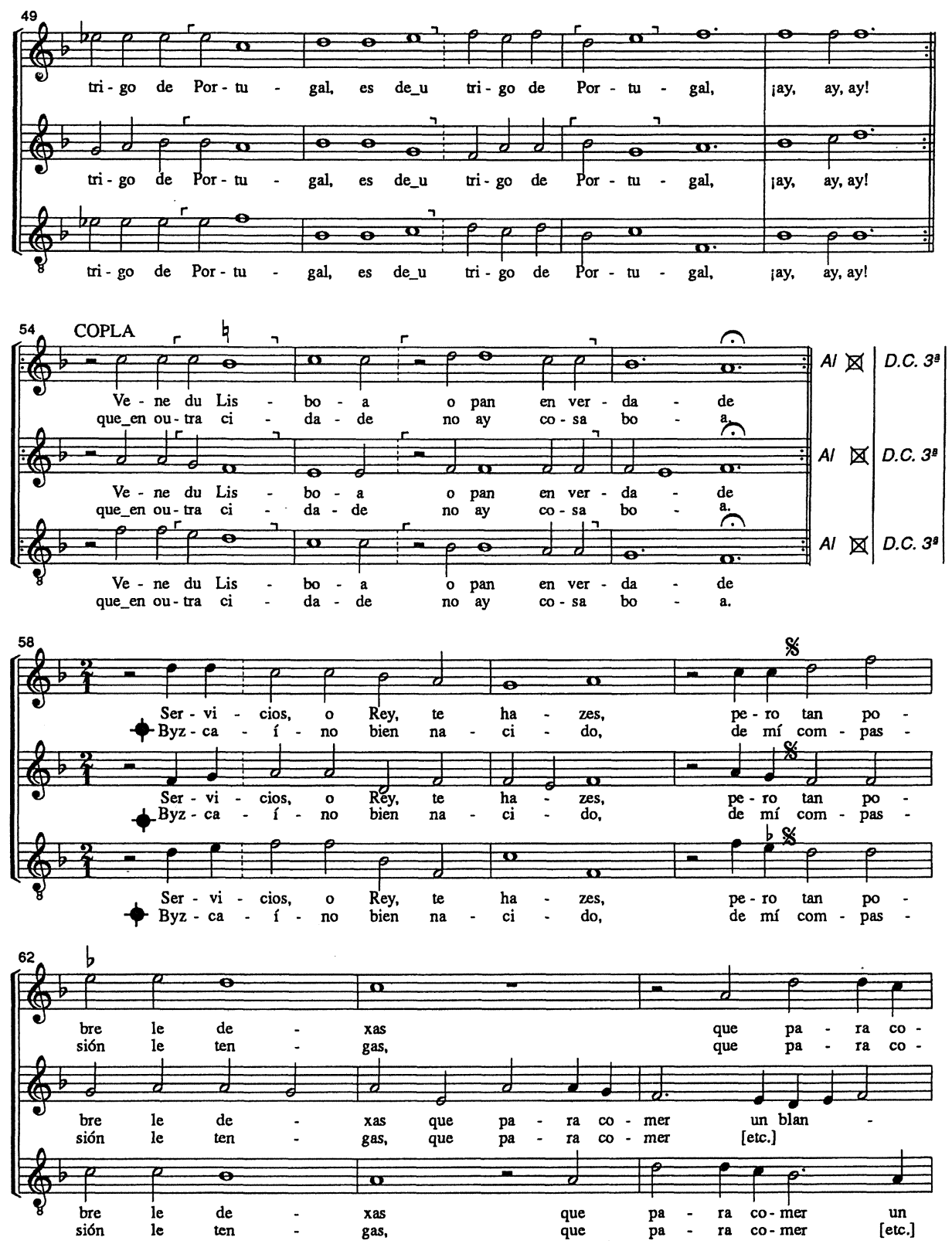

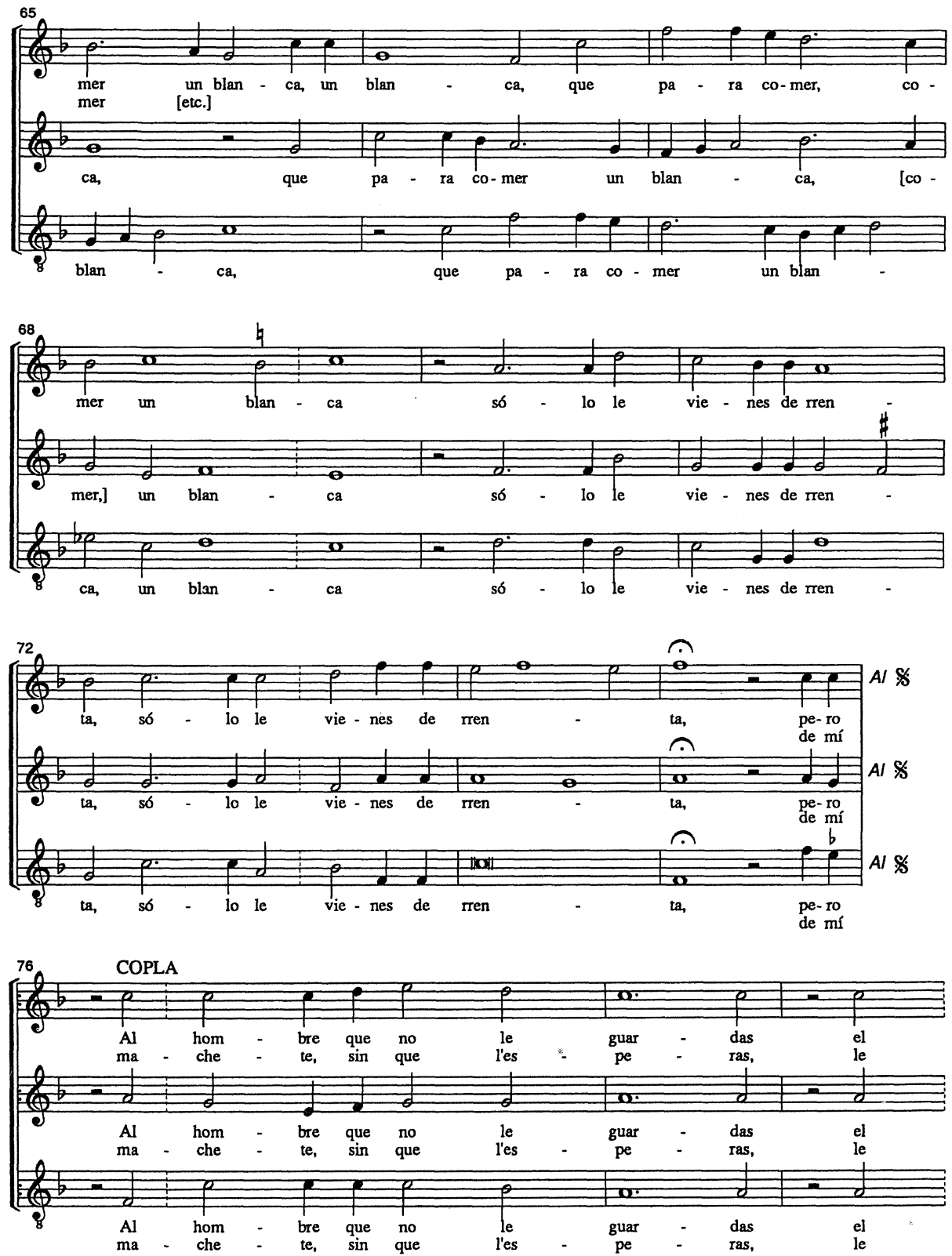

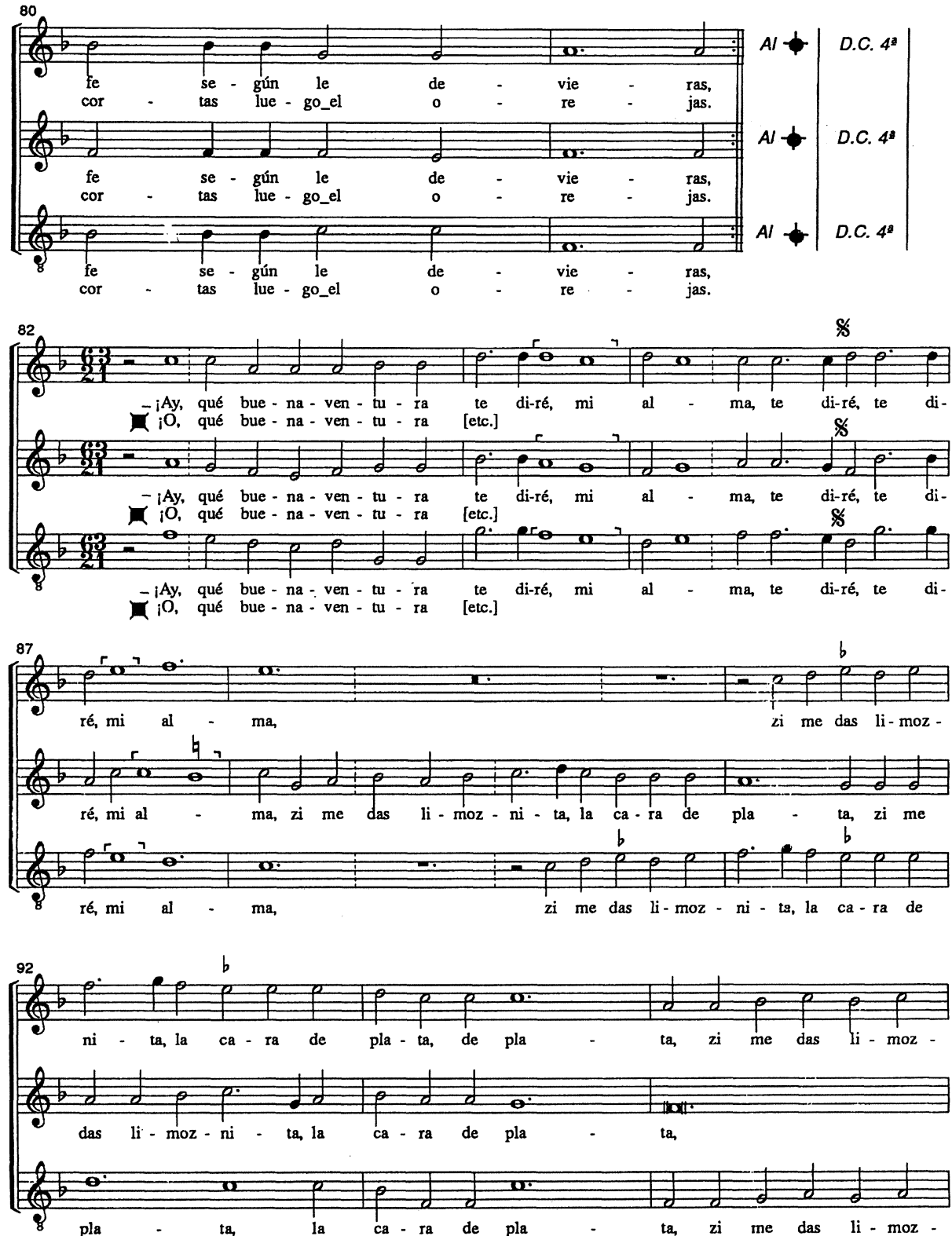

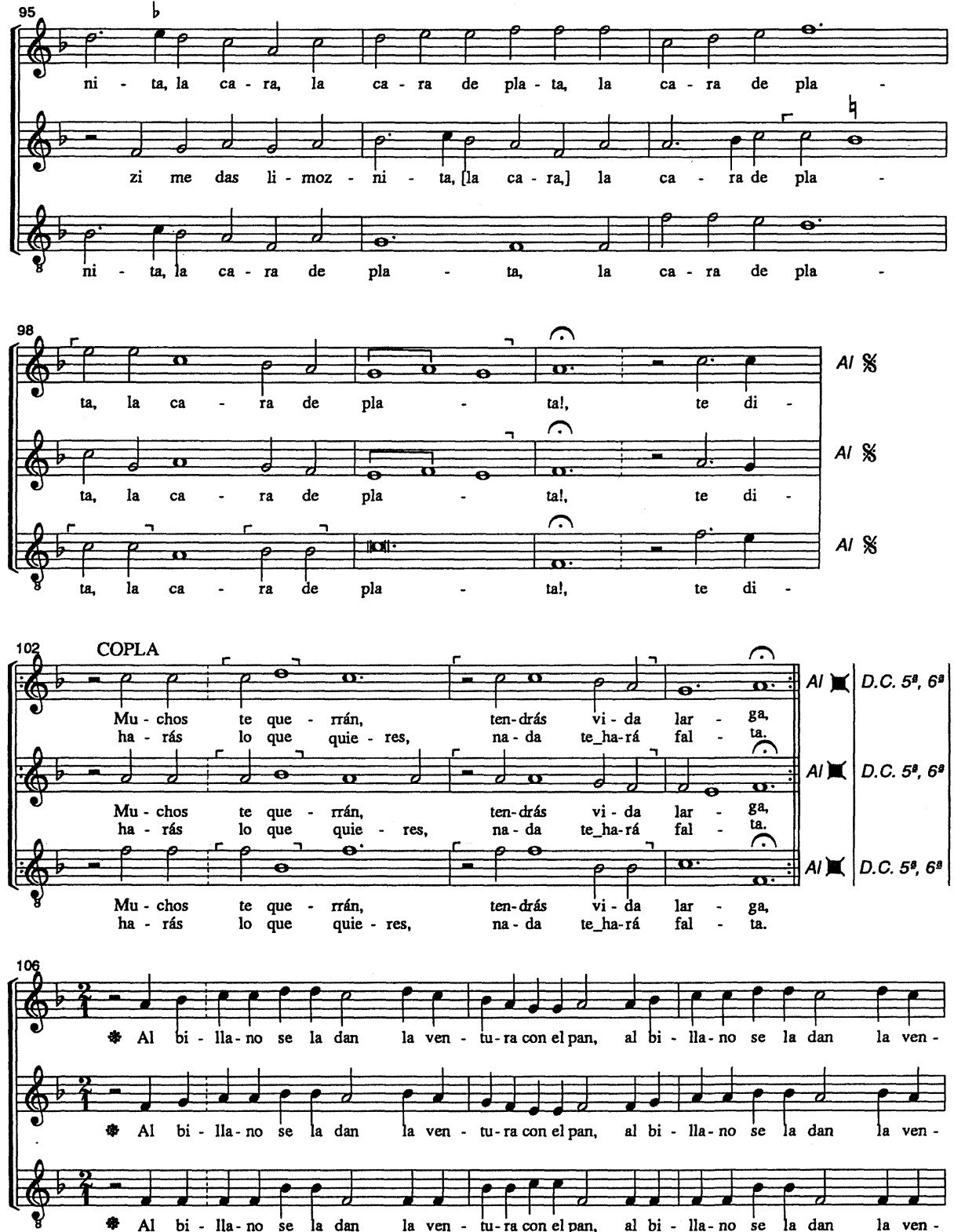

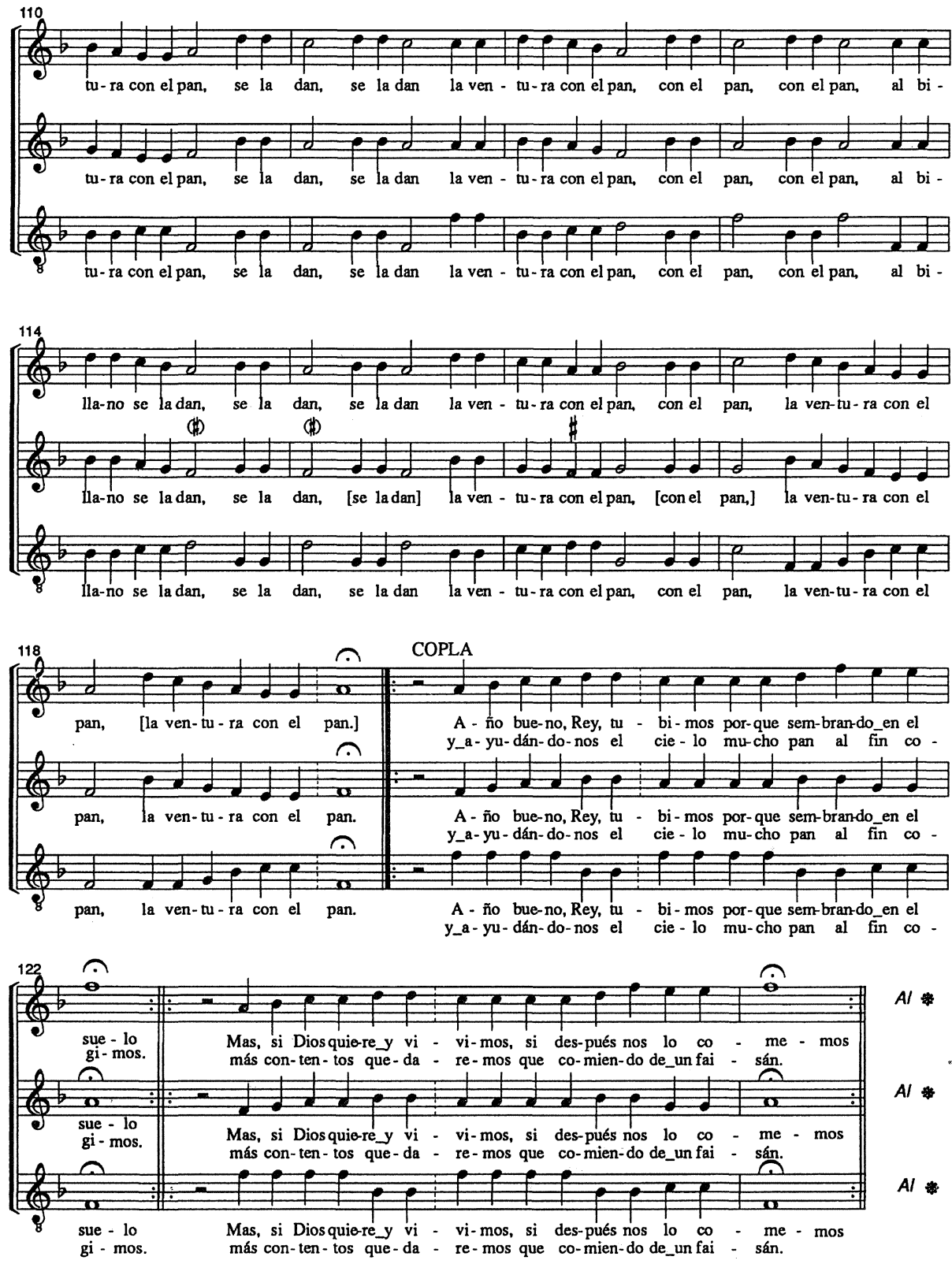